\title{
Proinflammatory cytokines and viral respiratory disease in pigs
}

\author{
Kristien VAN REETH*, Hans NAUWYNCK \\ Laboratory of Virology, Faculty of Veterinary Medicine, Ghent University, Salisburylaan 133, \\ 9820 Merelbeke, Belgium
}

(Received 26 July 1999; accepted 16 December 1999)

\begin{abstract}
Swine influenza virus (SIV), porcine respiratory coronavirus (PRCV) and porcine reproductive and respiratory syndrome virus (PRRSV) are enzootic viruses causing pulmonary infections in pigs. The first part of this review concentrates on known clinical and pathogenetic features of these infections. SIV is a primary respiratory pathogen; PRCV and PRRSV, on the contrary, tend to cause subclinical infections if uncomplicated but they appear to be important contributors to multifactorial respiratory diseases. The exact mechanisms whereby these viruses cause symptoms and pathology, however, remain unresolved. Classical studies of pathogenesis have revealed different lung cell tropisms and replication kinetics for each of these viruses and they suggest the involvement of different lung inflammatory responses or mediators. The proinflammatory cytokines interferon- $\alpha$ (IFN- $\alpha$ ), tumour necrosis factor- $\alpha$ (TNF- $\alpha$ ) and interleukin-1 (IL-1) have been shown to play key roles in several respiratory disease conditions. The biological effects of these cytokines and their involvement in human viral respiratory disease are discussed in the second part of this review. The third part summarises studies that were recently undertaken in the authors' laboratory to investigate the relationship between respiratory disease in pigs and bioactive lung lavage levels of IFN- $\alpha$, TNF- $\alpha$ and IL- 1 during single and combined infections with the above viruses. In single SIV infections, typical signs of swine "flu" were tightly correlated with an excessive and coordinate production of the 3 cytokines examined. PRCV or PRRSV infections, in contrast, were subclinical and did not induce production of all 3 cytokines. Combined infections with these 2 subclinical respiratory viruses failed to potentiate disease or cytokine production. After combined inoculation with PRCV followed by bacterial lipopolysaccharide, both clinical respiratory disease and TNF- $\alpha / \mathrm{IL}-1$ production were markedly more severe than those associated with the respective single inoculations. Taken together, these data are the first to demonstrate that proinflammatory cytokines can be important mediators of viral respiratory diseases in pigs.
\end{abstract}

cytokines / pathogenesis / swine influenza virus (SIV) / porcine respiratory coronavirus (PRCV) / porcine reproductive and respiratory syndrome virus (PRRSV)

Résumé - Cytokines proinflammatoires et maladies respiratoires virales chez le porc. Le virus de la grippe porcine (swine influenza virus, SIV), le coronavirus respiratoire porcin (porcine

* Correspondence and reprints

Tel.: (32) 926473 65; fax: (32) 926474 95; e-mail: kristien.vanreeth@rug.ac.be 
respiratory coronavirus, PRCV), et le virus du syndrome dysgénésique et respiratoire porcin (porcine reproductive and respiratory syndrome virus, PRRSV) sont des virus enzootiques provoquant des infections pulmonaires chez le porc. Les caractéristiques cliniques et pathogénétiques de ces infections sont données dans la première partie de cette revue. Le SIV est un agent pathogène respiratoire primaire ; les PRCV et PRRSV, en revanche, ne causent que des infections subcliniques en l'absence de complications, mais ils contribuent de manière importante aux maladies respiratoires multifactorielles. Cependant, les mécanismes précis par lesquels ces virus provoquent des symptômes et une pathologie demeurent inconnus. Les études classiques de pathogenèse ont révélé un tropisme pour les cellules pulmonaires et des cinétiques de réplication différents pour chacun de ces virus, et suggèrent l'implication de différents types de réponses ou de médiateurs inflammatoires pulmonaires. Il a été démontré que les cytokines proinflammatoires interféron- $\alpha$ (IFN- $\alpha$ ), facteur de nécrose tumorale- $\alpha$ (tumour necrosis factor, TNF- $\alpha$ ) et interleukine-1 (IL-1) jouaient un rôle clé dans plusieurs cas de maladies respiratoires. Les effets biologiques de ces cytokines et leur implication dans les maladies respiratoires virales chez l'humain sont discutés dans la seconde partie de cette revue. La troisième partie résume les études qui ont été entreprises récemment dans le laboratoire des auteurs pour étudier la relation entre les maladies respiratoires chez le porc et les quantités bioactives d'IFN- $\alpha$, de TNF- $\alpha$ et d'IL-1 retrouvées suite à des lavages pulmonaires, au cours d'infections simples et combinées avec ces virus. Dans le cas d'infections simples à SIV, les signes typiques de grippe porcine étaient étroitement corrélés à la production excessive et coordonnée des 3 cytokines examinées. Par contre, les infections PRCV ou PRRSV étaient subcliniques et ne pouvaient pas induire la production des 3 cytokines. Les infections combinées avec ces 2 virus respiratoires subcliniques n'ont pas eu d'effet potentialisateur sur la maladie ou la production de cytokines. Par contre, après une inoculation combinée avec PRCV suivi d'un lipopolysaccharide bactérien, la maladie respiratoire clinique et la production de TNF- $\alpha$ et d'IL-1 ont été sensiblement plus sévères que lors des inoculations simples correspondantes. L'ensemble de ces données montre, pour la première fois, que les cytokines proinflammatoires peuvent être d'importants médiateurs des maladies respiratoires virales chez le porc.

cytokines / pathogénie / virus de la grippe porcine / coronavirus respiratoire porcin / virus du syndrome dysgénésique et respiratoire porcin

\section{Table of contents}

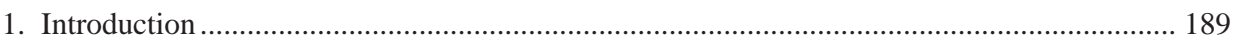

2. Current knowledge on the pathogenesis of porcine respiratory viruses................................. 189



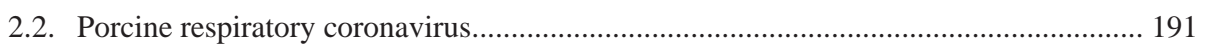

2.3. Porcine reproductive and respiratory syndrome virus.................................................. 192



3.1. Biology of interferons, tumour necrosis factors and interleukin-1 ................................ 194



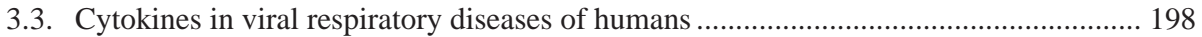

4. Growing evidence for a role of cytokines in pulmonary virus infections of pigs..................... 200

4.1. Cytokine profiles correlate with intrinsic pathogenicity of respiratory viruses ............. 200

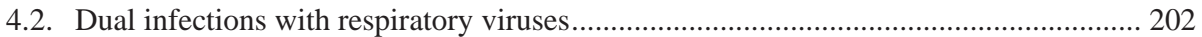

4.3. Interactions between respiratory viruses and bacterial lipopolysaccharides....................... 205

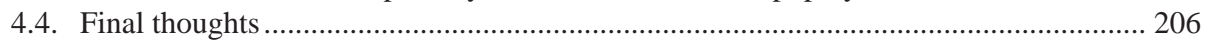






\section{INTRODUCTION}

Respiratory disease continues to be the greatest cause of economic losses to modern swine production. There has been relatively little progress in the control of respiratory disease over the past 15 years, despite the continuous development of new vaccines and antibiotics. Infections with respiratory viruses (swine influenza virus (SIV), porcine respiratory coronavirus (PRCV), porcine reproductive and respiratory syndrome virus (PRRSV)) form part of the respiratory disease problem. The physical, antigenic and genetic characteristics of these viruses, their epidemiology, transmission and diagnosis have been well studied. Their exact clinical significance and economic impacts, however, are frequently a matter of debate. PRRSV, for example, is recognised as a primary respiratory pathogen by some researchers, and considered insignificant by others. Similarly, the multifactorial nature of respiratory disease was accepted long ago, but there are few proven examples of microorganisms or circumstances that can combine to produce respiratory disease. Above all, there are serious gaps of knowledge concerning the disease mechanisms of respiratory viruses. While the tissue and cell tropism and the pathological manifestations of these viruses are known, information regarding the host response to these infections and the cellular/molecular basis of disease is comparatively scarce. More fundamental knowledge could prove extremely helpful in the development of novel, rational preventive and therapeutic strategies.

Cytokines are involved in many pathophysiological processes of the body. They act as intercellular messengers and exert potent biological effects at extremely low concentrations. The so-called early response or proinflammatory cytokines (interferon$\alpha$ (IFN- $\alpha$ ), tumour necrosis factor- $\alpha$ (TNF- $\alpha$ ) and interleukin-1(IL-1)) are produced during the most early stages of inflammation or infection, in an antigen-independent way. Several of these cytokines appear to play critical roles in infectious or non-infectious respiratory disease conditions, such as the adult respiratory distress syndrome and bronchial asthma in humans, and Gram-negative bacterial infections of the lungs in several animal species. As for viral respiratory diseases, information on the role of these cytokines is still very limited. Furthermore, interactions between viruses and cytokines have been largely studied in vitro, in isolated cell populations removed from their normal context that so profoundly influences the response of cells to cytokines, and in mice models. Virus-cytokine studies in pigs have been largely neglected. This has led us to test the hypothesis that an excessive production of IFN- $\alpha$, TNF- $\alpha$ and IL- 1 correlates with lung pathology and disease during infections with the above mentioned viruses.

This article is meant to review: (1) The current knowledge on the clinical and pathogenetic features of SIV, PRCV and PRRSV; (2) The potential biological effects of IFN- $\alpha$, TNF- $\alpha$ and IL-1, and studies on the involvement of these cytokines in viral respiratory diseases of humans; (3) Recent studies that were undertaken in our laboratory to examine the relationship between cytokines and disease in single and combined respiratory virus infections of pigs.

\section{CURRENT KNOWLEDGE ON THE PATHOGENESIS OF PORCINE RESPIRATORY VIRUSES}

Swine influenza virus (SIV), porcine respiratory coronavirus (PRCV) and porcine reproductive and respiratory syndrome virus (PRRSV) are readily transmitted via the respiratory route, and the respiratory tract is the only (SIV, PRCV) or main (PRRSV) route of virus entry. Pigs become infected with these viruses by air or by close contact with infected animals. These 3 viruses are ubiquitous in swine producing areas of the world. In intensive swine-rearing areas 
such as Belgium, nearly $100 \%$ of swine farms test positive for antibodies against H1N1-and H3N2-subtype influenza viruses, PRCV and PRRSV. All 3 viruses replicate extensively in the lungs of pigs, but experimental studies point out differences in lung cell tropism and replication kinetics and suggest differences in pathological characteristics. The clinical impact of each of these virus infections is frequently a matter of debate. As for most respiratory viruses, there is extreme variability in the response to experimental infection. A virus that fails to induce any symptoms in the hands of some researchers, may be associated with significant respiratory disease by others. It is apparent that the variety of experimental conditions used (virus dose, virus inoculation route, virus strain, age and sanitary status of pigs) is at least partially responsible for these discrepancies. Direct comparative studies of the 3 virus infections have not been undertaken, but critical reading of experimental studies together with close consideration of field data allows to more or less judge the clinical significance of SIV, PRCV and PRRSV.

\subsection{Swine influenza virus}

Swine influenza viruses (SIVs) are type A influenza viruses, in the family Orthomyxoviridae. The epidemiology of SIVs is particularly complex and differs in different geographical areas of the world. Three SIV subtypes with a different antigenic makeup are circulating in swine in Europe, while only 1 subtype is widespread in the US. In most European countries, virus subtypes with the haemagglutinin/neuraminidase configuration $\mathrm{H} 1 \mathrm{~N} 1$ and $\mathrm{H} 3 \mathrm{~N} 2$ are enzootic $[41,47,75,140]$. The prevailing H1N1 virus is of avian origin and was introduced in European pigs in 1979 [97]. The H3N2 virus was transferred from humans to pigs in Asia in 1969 and later disappeared from the human population [69]. Swine H1N1 and H3N2 influenza viruses are related to, but clearly distinguishable from, the currently circulating human viruses. A third virus subtype, H1N2, has become very common in the UK since the 1980s [24]. There is no cross-immunity between virus subtypes and fattening pigs frequently contract infections with 2 or more influenza viruses within their relatively short lifetime. There is no doubt that SIVs of all 3 subtypes can act as primary respiratory pathogens. In Belgium and in the Netherlands, SIVs are the most commonly identified agents in acute respiratory outbreaks in swine herds. In a 1995 diagnostic survey in the Midwestern US, SIV was demonstrated in approximately $25 \%$ of pneumonic lung tissue samples (Bruce Janke, personal communication). Typical outbreaks of swine influenza (SI) are characterised by a sudden onset of coughing, laboured jerky breathing, fever, anorexia, muscular weakness and weight loss. Morbidity is high, but mortality is usually less than $1 \%$, and recovery is almost as sudden as the onset. In addition to the clinical SI outbreaks, subclinical infections frequently occur and secondary bacterial infections often increase disease severities and mortality rates.

Infection with SIV is generally limited to the respiratory tract. In experimental infections, virus replication has been demonstrated in nasal mucosa, tonsils, trachea, and lungs $[72,86]$. Low virus titres have occasionally been isolated from serum [23], but virus isolation from extra-respiratory sites was negative. In the lungs, massive virus replication occurs in epithelial cells of bronchi, bronchioli and alveoli. Virus titres in the lungs may reach up to $10^{8} 50 \%$ egg infectious doses $\left(\mathrm{EID}_{50}\right)$ /gram lung tissue [49] and immunofluorescence studies may show infection of nearly $100 \%$ of the epithelial lining of bronchi/bronchioli. In most experimental studies, virus clearance was extremely rapid. SIV could not be isolated from lungs or other respiratory tract tissues on or after day 7 [23]. Influenza specific antibodies have been detected in the serum 
and nasal swabs as early as 3 and 4 days post inoculation (DPI) respectively [77].

The characteristic histopathological lung lesions include detachment of large areas of bronchial/bronchiolar epithelium and accumulation of necrotic epithelial cell debris and neutrophils in the airspaces. Later, the airways are filled with exudates containing monocytes and lymphocytes [48]. There is often extensive lung consolidation at the macroscopic level, with a sharp line of demarcation between the affected, red and firm lung parts and normal lung tissue.

Though swine are readily infected by experimental SIV inoculation, the typical clinical picture can be reproduced under very specific conditions only. In fattening swine $( \pm 100 \mathrm{~kg})$, direct inoculation of high virus doses $\left(10^{7}-10^{7.5} \mathrm{EID}_{50}\right.$ per pig) into the trachea of either the H1N1 or H3N2 subtype, results in high fever, complete anorexia and severe respiratory distress within $24 \mathrm{~h}$ post inoculation (h PI) [48, 49], and mean weight losses of 5-6 kg during the first week PI. Still, recovery is rapid and symptoms persist only for 2 or 3 days. In contrast, inoculation of the same amount of virus by the less invasive oronasal route produces mild clinical signs or an asymptomatic infection. The underlying causes for the variety of clinical severities are undiscovered.

\subsection{Porcine respiratory coronavirus}

PRCV is a deletion mutant of transmissible gastroenteritis virus (TGEV) of pigs (reviewed in [74]). Unlike TGEV, PRCV causes a respiratory tract infection with minimal or no intestinal replication. PRCV first appeared in Europe in 1984 [98] and in the USA in 1989 [148]. The virus has spread more rapidly and extensively in Europe (where it has become enzootic [47, 75, 140]) than in the US, but recent data indicate that PRCV seroprevalence in Midwestern states may be increasing [149]. PRCV is generally considered as non-pathogenic, because as a rule infection on swine farms passes without being noticed by the pig keeper. Recent field data, however, indicate that PRCV may be involved in respiratory disease problems in conjunction with PRRSV or bacteria, such as Haemophilus parasuis, Streptococcus suis and Pasteurella multocida [50, 65].

Experimental infection studies have shown that PRCV replicates readily in epithelial cells of nasal mucosa, tonsils and lungs $[35,36,92]$. Viraemia is detected in very young pigs $(\leq 1$ week) only, and parenchymal organs and lymph nodes are virus-negative in immunofluorescence studies. High amounts of virus are isolated from the lungs $\left(10^{7.5}-10^{8.3} 50 \%\right.$ tissue culture infectious doses $\left(\mathrm{TCID}_{50}\right) / \mathrm{g}$ tissue) and from nasal swabs $\left(10^{6.5}-10^{7.3} \mathrm{TCID}_{50} / 100 \mathrm{mg}\right.$ secretions) during the first week after inoculation [35, 36, 139]. PRCV was detected in several types of lung cells (bronchial and bronchiolar epithelial cells, type I and II pneumocytes, alveolar and septal macrophages) using antigen detection methods $[35,36,92,114]$ and different experimental studies yielded conflicting data as to the main virus target cell. In studies with Belgian PRCV isolates, cells of the alveolar epithelia and septa were predominantly infected [35, 36], while US isolates were shown to replicate mainly in bronchiolar epithelial cells [114]. Nasal virus excretion continues until 8-9 DPI [21, 72, 138, 139] suggesting a similar duration of virus replication in the lungs. Virus neutralising antibodies in serum are detectable by $10-14$ DPI [72, 135].

Microscopic examination of the lungs of experimentally infected pigs reveals a mild to moderate broncho-interstitial pneumonia. Lesions mainly involve smaller bronchioli, alveolar ducts and peribronchiolar alveoli. They are characterised by peribronchiolar and septal infiltration with mononuclear cells, bronchiolar and alveolar lymphohistiocytic exudate, and occasional epithelial cell necrosis $[35,50,92]$. The reparative process starts at approximately 1 week PI [92]. The lungs are grossly 
consolidated and the $\%$ of affected lung tissue varies depending on the PI time [50, 92]. Different US PRCV isolates have been reported to differ in the extent of lung pathology [51].

The clinical outcomes of experimental PRCV infections appear to depend largely on the sanitary status of pigs. Under strictly gnotobiotic circumstances, both European and US PRCV isolates fail to induce clinical disease, despite considerable lung pathology $[35,50,92,148]$. In some of the specific pathogen free (SPF) or conventional pig studies using pigs of various ages and various inoculation methods, mild dyspnoea and polypnoea and a short lasting fever $[48,135$, 138] or fever without respiratory signs [21, $40,72]$ have been observed. Slightly reduced weight gains have also been recorded. In many clinical studies, the pigs were not uniformly affected. As for lung pathological lesions, the American PRCV isolates differ in their ability to induce clinical signs in conventional pigs and these differences might relate to different genome deletions [95]. To test the hypothesis that the severity of disease induced by PRCV depends on concurrent infection, experimental combined infections with PRCV followed by SIV [72, 139], and with PRRSV followed by PRCV [141] were performed. The clinical effects of such dual virus infections were more severe than the single virus infections in some but not in all studies.

\subsection{Porcine reproductive and respiratory syndrome virus}

PRRSV is an arterivirus of the swine (reviewed in [5]). The virus was first noticed in the USA in 1987 [30] and subsequently in Europe in 1990 [2, 12, 124] and has become enzootic on both continents. Antigenic differences have been reported between European and North American PRRSV isolates, and among different US PRRSV isolates [88]. The role of the virus in respiratory disease is difficult to define. In many herds, infection with PRRSV is subclinical and productivity does not seem to be affected. There has, however, been a general increase in respiratory disease and poor productivity since the enzootic appearance of PRRSV, and there are serious indications that PRRSV may cause respiratory disease and/or poor doing in combination with other infectious agents. In problem herds, PRRSV has been isolated along with a mixture of bacteria (Actinobacillus pleuropneumoniae, Mycoplasma hyopneumoniae, Mycoplasma hyorhinis, Haemophilus parasuis, Actinomyces pyogenes, Streptococcus suis) and with common respiratory viruses, notably SIV and PRCV [50, 65, 66, 118, 152].

In contrast to SIV and PRCV, PRRSV causes a generalised infection. The virus most frequently enters via the respiratory tract, but viraemia and dissemination rapidly occur throughout the body. Transplacental infection occurs in late gestating sows, but is beyond the scope of this review. In experimentally infected pigs, PRRSV replicates in nasal turbinates, tonsils, lungs, several lymph nodes, spleen, liver, kidney, thymus, brain, heart, bone marrow and choroid plexus [32, 46, 101, 107]. Nasal secretions are inconsistently virus positive and plasma or serum samples are more appropriate for virus isolation than nasal swabs [32]. Macrophages are the principal virus target cells in all organs. In the lungs, PRRSV antigens have been detected in macrophages of the alveolar spaces and alveolar septa and, more rarely, in type 2 pneumocytes $[32,39$, 46]. On the contrary, only a small fraction of the total alveolar macrophage (AM) population (no more than about $2 \%$ of lavaged alveolar cells) are found to be PRRSV antigen positive [32, 39, 81]. The pathogenetic consequences of PRRSV replication in AMs are unknown and there is no substantial evidence that PRRSV infection causes local or general immunosuppression [6]. One particular feature of PRRSV is its capacity to persist in the infected pig for several weeks. In various experimental studies, virus replication peaks between 7 and 14 DPI [107] 
and peak virus titres are in the range of $10^{3.5}$ $10^{5.0} \mathrm{TCID}_{50} / \mathrm{g}$ lung. Though PRRSV specific serum antibodies appear within 2 weeks after exposure to the virus, virus clearance does not occur until 4-6 weeks PI [17, 39, 151]. While the virus can be recovered from most susceptible organs during the first 2 weeks, only some organs (lungs, serum, tonsils and lymph nodes) are found positive thereafter. Results of several studies indicate that the lungs are the major site of virus persistence and a source of viraemia [32, $39,81]$, but other studies suggest virus persistence in lymphoid tissues [107].

Mild histopathological lung changes have been recorded in most experimental studies and are mainly confined to the alveoli [32, 52, 101, 107]. Lesions typically consist of alveolar septal thickening with many macrophages and few lymphocytes. Interstitial pneumonia is of a prolonged nature, with most severe changes at 10 DPI, but inflammatory changes can persist until 28 DPI [106]. Remarkable gross lung lesions have been observed exclusively with some "more virulent" US PRRSV isolates [53].

Many clinical studies have been performed with pigs of different ages and sanitary status and using different PRRSV isolates and inoculation methods. With few exceptions, the experimental inoculation with PRRSV failed to induce overt respiratory disease. The most common clinical manifestation is a transient fever after 2-3 days [3, 89, 93, 100]. In some studies, inappetence and depression have been recorded [32]. Considerable respiratory distress, lethargy and anorexia have been reported with some selected US PRRSV isolates only [52-54]. These isolates are seemingly more virulent and more invasive for the lungs, lymph nodes and tonsils than other US PRRSV isolates and than the European Lelystad virus.

PRRSV is recognised as a key agent in multifactorial respiratory disease problems designated as the "porcine respiratory disease complex" (PRDC), but clinical disease has been difficult to reproduce in experimental infections with PRRSV and other agents. Galina et al. [43] provided limited experimental evidence for an interaction between PRRSV and a virulent strain of Streptococcus suis, but other workers failed to demonstrate synergisms between PRRSV and bacteria. Dual infections with PRRSV followed by Streptococcus suis, Salmonella choleraesuis, Pasteurella multocida, Mycoplasma hyopneumoniae or Haemophilus parasuis were all very mild or subclinical [4, 34, 116, 132]. Variable degrees of respiratory disease and growth retardation may result from infections with PRRSV followed by either PRCV or SIV [141].

\section{EARLY CYTOKINES AND THEIR INVOLVEMENT IN RESPIRATORY DISEASE}

Cytokines - the term is derived from the ancient Greek words "cytos" (cell) and "kinein" (to move) - are essential transmitters of cell-to-cell communication in physiological and pathophysiological states. Cells in any compartment of the body are capable of cytokine production. In most instances, cytokines are produced in response to stimulation, and after withdrawal of the stimulus, production stops. A variety of agents including viruses, bacteria, components of moulds and noxious agents can interact with specific components of the cell surface membrane or cytoplasm to trigger cytokine gene activation and expression. Intracellular pathogens like viruses can also trigger cytokine gene expression via molecules generated during their replication cycle. In addition, many cytokines can themselves induce cytokine production. Cytokines generally function in an autocrine (on the cytokineproducing cell itself) or paracrine (on nearby cells) manner.

Cytokines released following infection can be classified broadly into "early" and "late" cytokines. Early cytokines are 
produced by (non-immune) cells at the site of infection and they are responsible for local inflammatory reactions as well as some systemic effects. Interferon- $\alpha$ (IFN- $\alpha)$, the proinflammatory cytokines such as interleukin-1 (IL-1), tumour necrosis factor- $\alpha$ (TNF- $\alpha$ ) and interleukin-6 (IL-6), as well as a number of chemotactic cytokines such as interleukin- 8 and the macrophage inflammatory proteins belong to the group of early cytokines. IFN- $\alpha$, TNF- $\alpha$ and IL- 1 theoretically stand most proximal in the early cytokine cascade and have been the focus of our virus-cytokine studies in pigs. In contrast, late cytokines are produced by $\mathrm{T}$ cells after recognition of antigens in association with major histocompatibility complex (MHC) molecules on the surface of antigen-presenting cells. These cytokines are important in the regulation of the specific immune response to infection and are beyond the scope of this review.

The actions of cytokines and the cytokine response to viruses have been studied mainly in vitro, in isolated cell populations removed from their normal context. One must be extremely careful when extrapolating from in vitro results to an in vivo situation for several reasons. Cytokine production is highly dependent upon the cell type and conflicting data have often been obtained with one virus in different cell types. Also, as explained before, cytokines are part of a complex in vivo network and the microenvironments in which they occur affect their production and actions. In this review, therefore, we will try to emphasise in vivo data of cytokine involvement in respiratory disease pathogenesis wherever possible.

The aim of this chapter is to illustrate certain aspects of the involvement of early cytokines (IFN- $\alpha$, TNF- $\alpha$ and IL- 1 in particular) in the pathophysiology of viral respiratory disease. First, a brief introduction on interferons, tumour necrosis factors and interleukin-1 is made elucidating the complex nomenclature of these cytokines. Thereafter, the potential biological activities of IFN- $\alpha$, TNF- $\alpha$ and IL- 1 are summarised, specifically as they relate to respiratory infections. Finally, data about cytokines in the pathogenesis of respiratory virus infections are discussed.

\subsection{Biology of interferons, tumour necrosis factors and interleukin-1}

The interferons (IFNs) are grouped into 2 main types: type I and type II IFNs. Type II IFN or IFN- $\gamma$ is unrelated to type I IFNs and is produced after antigen specific or mitogenic stimulation of $\mathrm{T}$ lymphocytes and natural killer cells. IFN- $\gamma$ is thus a "late" cytokine and will not be treated further. Type I IFNs are a large family of several related subtypes of IFN- $\alpha$ (more than 12 subtypes in humans and pigs) and IFN- $\beta$ (1 subtype in humans; multiple subtypes in pigs and ruminants). The more recently discovered type I IFN- $\omega$ and IFN- $\tau$ do not seem to play a role in virus infection and are left aside. Virus infection mostly induces a mixture of different IFN- $\alpha$ subtypes and IFN- $\beta$ and virus-induced IFN is therefore commonly designated as IFN- $\alpha / \beta$. IFN- $\alpha$ and IFN- $\beta$ were originally named leukocyte and fibroblast IFN respectively, according to their main producer cells, but it later turned out that many other cell types can produce these IFNs. IFN- $\alpha$ and $-\beta$ subtypes are closely related, share a common receptor and hence have similar effects. One characteristic property, which forms the basis of biological assays quantifying IFNs, is their ability to induce an antiviral state in target cells.

There are 2 important related tumour necrosis factors (TNFs). TNF- $\alpha$, commonly referred to as TNF, is produced by activated macrophages and monocytes and various other cell types. TNF- $\beta$ is a lymphocyte product induced by antigenic stimuli and is called "lymphotoxin". Production of TNF- $\alpha$ generally occurs at an earlier stage during infection than that of TNF- $\beta$. They bind to common receptors and share several biological activities, but TNF- $\alpha$ is more closely 
associated to proinflammatory effects. TNF- $\alpha$ and TNF- $\beta$ are cytostatic and cytocidal for neoplastic cells and they are often assayed by in vitro "cytotoxicity assays". We will further focus on TNF- $\alpha$.

There are 2 forms of interleukin-1 (IL-1) in all species, IL- $1 \alpha$ and IL- $1 \beta$, and porcine IL- $1 \beta$ exists in 2 forms [134]. IL- 1 s are synthesised by macrophages-monocytes and many other cell types. Although IL- $1 \alpha$ and $\beta$ proteins have only about $25 \%$ homology, they bind to the same receptors and have identical biological effects. IL-1 was originally named "lymphocyte activating factor", because it stimulates lymphocyte proliferation in the presence of suboptimal doses of mitogen. This effect forms the basis of several biological assays. Pure IL- $1 \alpha$ and IL- $1 \beta$ are equipotent in all bioassays and specific antibodies are needed to distinguish between them.

For details about the molecular biology of porcine IFN- $\alpha$, TNF- $\alpha$ and IL- 1 , the reader is referred to excellent review articles [78, 96, 133].

\subsection{Cytokine effects on the respiratory tract}

Proinflammatory cytokines usually remain compartmentalised in the area of the body where they are produced. During pulmonary infections cytokine production is mainly restricted to the lung and it seems that diffusion of cytokines across the bloodalveolar barrier is rather limited [87]. Consequently, the highest amounts of cytokines are detected at the lung level, and plasma cytokine levels are generally low or undetectable $[11,33]$. This situation contrasts with that seen during septicaemia, where endothelial and blood cells are the primary cytokine producers and systemic effects, such as shock and multiple organ failure, predominate. Still, the activities of cytokines produced in the respiratory tract may be represented in both local and systemic effects. Even compartmentalised production of IL-1 can mediate fever and probably other central nervous system responses as demonstrated in a rat model [79], though the afferent pathways involved are not entirely clear. This may be partially responsible for the close correlation that is often seen between cytokine production in the respiratory tract and systemic disease [45]. Both the local and systemic effects of IFN- $\alpha$, TNF- $\alpha$ and IL-1 are discussed here.

At the lung level, early cytokines exert their most potent effects on phagocytic cells.

Neutrophil infiltration of the lungs is one of the first and most important events during pulmonary inflammation. Both TNF- $\alpha$ and IL-1 induce a striking increase in intra-alveolar neutrophils when injected intratracheally into rats [129]. Neutrophils peak within 12-24 h after administration of cytokines, and return to baseline levels after $48 \mathrm{~h}$. A smaller influx of monocytes and lymphocytes is seen at 24 and $72 \mathrm{~h}$ respectively. The process of neutrophil infiltration involves a series of steps: expression of endothelial cell adhesion molecules, neutrophil-endothelial cell adhesion, neutrophil activation and expression of neutrophilderived adhesion molecules, neutrophil diapedesis and migration beyond the vascular barrier along a neutrophil-specific chemotactic gradient. Both TNF- $\alpha$ and IL-1 strongly upregulate or induce the adhesion molecules (intercellular adhesion molecule-1 (ICAM-1), E-selectin and P-selectin) on the vascular endothelium [119]. Other effects by which these cytokines can facilitate neutrophil sequestration in the lungs include adhesion molecule expression on neutrophils and on the respiratory epithelium [119, 126] and induction of chemoattractant cytokines, such as IL-8, by endothelial, lung epithelial or inflammatory cells [70]. TNF- $\alpha$ and IL1 were initially reported to have direct chemotactic activities. The current view, however, is that TNF- $\alpha$ and/or IL- 1 are essential to the initial adhesive reaction of neutrophils to the microvascular endothelium of the lung, but that IL- 8 or other chemokines are necessary for the directed 
migration of leukocytes into the lung [19, 113]. The recent finding that cytokineinduced expression of endothelial cell adhesion molecules is differentially regulated in different tissues and cell types [121] is another example of the complex regulation of leukocyte recruitment. Besides neutrophil chemoattractants, TNF- $\alpha$ and IL- 1 also induce chemokines with selective macrophage attracting properties, such as monocyte chemoattractant protein-1 [117].

Once neutrophils have arrived in the lungs, TNF- $\alpha$ and IL- 1 may exert profound stimulating effects on neutrophil function. In vivo, the TNF- $\alpha /$ IL- 1 associated neutrophilic exudate has been linked to an increased phagocytic capacity of the lung, with release of enzymes from neutrophils and with respiratory burst activity. The local release of enzymes from neutrophils probably makes important contributions to lung tissue injury and increased vascular permeability with resultant lung haemorrhages and edema [94, 129]. In vitro studies have demonstrated stimulating effects of TNF- $\alpha$ and IL-1 on both neutrophils and macrophages of several animal species. As an example, bovine and porcine neutrophils treated with TNF- $\alpha$ showed increased phagocytosis, degranulation, and respiratory burst activity [29, 31, 109] and similar effects have been observed for bovine neutrophils incubated with IL-1 [109]. Yet, these in vitro studies must be evaluated with caution, because conflicting results have often been reported. Neutrophils and macrophages can produce several inflammatory cytokines and mediators, including platelet activating factor, leukotrienes and arachidonic acids in response to TNF- $\alpha$ or IL-1. One interesting finding is that newly recruited neutrophils may serve as important sources of extra TNF- $\alpha / \mathrm{IL}-1$ production during acute lung injury in rabbits [63]. It is equally intriguing how neutrophils can in turn downregulate TNF- $\alpha$ bioactivity. Activated human neutrophils have been shown to release proteolytic enzymes that cause inactivation of TNF- $\alpha$ [136] and they can shed TNF- $\alpha$ receptors that may decrease the responsiveness of neutrophils and other cells to TNF- $\alpha$ [102]. Such events will probably help to regulate the local inflammatory reaction and to protect the host against the deleterious effects of TNF- $\alpha$.

For IFN- $\alpha$, substantial evidence for a role in leukocyte recruitment to the lungs is lacking. Unlike TNF- $\alpha$ and IL-1, the effects of intratracheal administration of exogenous IFN- $\alpha$ have not been studied. Both pro- and anti-inflammatory effects on airway cell populations have been reported after oral or systemic administration of IFN- $\alpha$ in domestic animals [84]. Still, limited experimental data suggest that IFN- $\alpha$ may be involved in tissue lymphocyte or neutrophil infiltration. For example, local production of IFN- $\alpha / \beta$ in the lungs of virus-infected calves is temporally correlated with an influx of $\mathrm{CD} 8+\mathrm{T}$ lymphocytes into the lung parenchyma [46]. Also, virus-induced IFN- $\alpha / \beta$ production in the lymph nodes of mice is associated with a striking neutrophil infiltration [104]. Furthermore, IFN- $\alpha$ augments the expression of the adhesion molecules B 7.2 and ICAM-1 in cultures of endothelial cells [28]. Neutrophil- and macrophage-activating effects, as reported for TNF- $\alpha$ and IL-1, have also been observed in in vitro studies (reviewed in [125]).

TNF- $\alpha$ and IL- 1 are both associated with bronchial hyperresponsiveness in animal models of obstructive disease [67]. Bronchoconstriction may result from increased synthesis of endothelin - a potent vasoconstrictor and bronchoconstrictor - in response to both cytokines [42]. Furthermore, it is worth mentioning that TNF- $\alpha$ and IL- 1 can directly or indirectly alter mucus secretion, ciliary beat frequency and surfactant production in cultured airway epithelial cells (reviewed in [1]). It is clear from the above information that TNF- $\alpha$ and IL-1 have multiple overlapping activities, but in a few cases they do counteract each other's effects. Production of pulmonary surfactant components, for example, is generally 
downregulated by TNF- $\alpha$, but enhanced by IL-1 (reviewed in [25]).

Theoretically all 3 cytokines discussed here have non-specific antiviral effects. IFN- $\alpha$ is the prototypic antiviral cytokine and induces an antiviral state in its target cells via the induction of specific antiviral proteins, e.g. 2', 5'-adenylate synthetase and protein kinase enzymes. The antiviral properties of interferons have been convincingly demonstrated in vivo. TNF- $\alpha$ and IL- 1 protect a rather limited number of cell lines from viral infection and synergise with interferons in the induction of an antiviral state (reviewed in $[73,150])$. According to some studies, the antiviral effects of TNF- $\alpha / \mathrm{IL}-1$ are mediated through the induction of IFN- $\beta$ or IL- 6 . In addition to protecting cells from viral infection, TNF- $\alpha$ selectively kills virusinfected cells in an IFN-independent way $[16,27]$. Furthermore, the 3 cytokines under study can significantly contribute to the nonspecific immune response through their effects on phagocytic functions.

The systemic effects of IFN- $\alpha$, TNF- $\alpha$ and IL-1 have been studied mainly by intramuscular or intravenous administration of these cytokines to experimental animals. The results of such studies are summarised briefly.

All 3 cytokines are pyrogenic. Fever results from intramuscular injection of either TNF- $\alpha$, IL- 1 or IFN- $\alpha$ in rabbits [38]. On a weight basis, IFN- $\alpha$ is less pyrogenic than TNF- $\alpha$ or IL-1. Pigs and goats experience fever in response to intramuscular injection of high doses of recombinant porcine and human IFN- $\alpha$, respectively [78, 137]. Intramuscular injections of recombinant bovine IL-1 $\beta$ to 9- to 11-day-old pigs caused a transient increase in rectal temperatures [112]. Excessive sleepiness and loss of appetite also result from the action of TNF- $\alpha$, IL-1 and IFN- $\alpha$ on the brain. Pigs injected intramuscularly with a high dose of recombinant bovine IL-1 $\beta$ display profound physiological effects, including vomiting and lethargy, and some pigs show central nervous system disturbances [20]. Similarly, intracerebroventricular injection of recombinant porcine TNF- $\alpha$ in pigs induces behavioural, metabolic and neuroendocrine responses resembling the responses of pigs that were injected peripherally with endotoxin [147].

TNF- $\alpha$ and IL- 1 produce characteristic acute phase effects in the liver. They mediate an increased uptake of plasma-Fe and $-\mathrm{Zn}$, and an increased synthesis of typical acute phase proteins by the liver. As a result, hypozincaemia, hypoferraemia, and elevated plasma concentrations of acute phase proteins occur. In cattle, 5 daily administrations of recombinant bovine IL-1 $\beta$ cause heightened and prolonged elevations of serum haptoglobin and fibrinogen, as well as $\alpha 1$-acid glycoproteins [44]. Some of these biochemical changes have also been observed with IFN- $\alpha$ [137]. Chronic exposure to TNF- $\alpha$ or IL- 1 results in cachexia and wasting, due to catabolic effects on muscle and fat cells. Prolonged treatment of cattle with recombinant bovine TNF- $\alpha$ is associated with a depletion of body fat depots [16].

The fact that IFN- $\alpha$, TNF- $\alpha$ and IL- 1 can synergise with each other, and induce each other is of major importance. With IL-1 and TNF- $\alpha$ in particular, synergistic interactions have been documented for several effects. For example, TNF- $\alpha$ synergises with IL-1 $\beta$ to promote ICAM-1 expression on endothelial cells [56]. Concentrations of TNF- $\alpha$ and IL-1 that do not induce superoxide production by macrophages alone do so in combination [122]. Also, the combination of both cytokines may lead to a secondary cytokine response that is 250-fold greater than that seen with each cytokine alone [26]. Furthermore, several systemic effects are enhanced when TNF- $\alpha$ and IL- 1 are administered together [37]. Finally, the ultimate effects of a given cytokine do not merely reflect its own and other cytokine concentrations, but also the levels of cytokine receptor expression and cytokine antagonists. The proteins involved in inflammatory cytokine 
action of TNF- $\alpha$ and IL- 1 are reviewed in detail by Murtaugh et al. [85].

\subsection{Cytokines in viral respiratory diseases of humans}

IFN- $\alpha$, TNF- $\alpha$ and IL- 1 can be induced in cells by viruses. IFN- $\alpha$ is classically associated with virus infection, and viruses are more potent IFN- $\alpha$ inducers than bacteria or bacterial products [115]. In contrast with IFN- $\alpha$, TNF- $\alpha$ and IL- 1 are induced by many stimuli other than virus infection. In monocyte-macrophage cultures, for example, TNF- $\alpha$ and IL- 1 are induced in response to Gram-negative and Gram-positive bacteria and their products (lipopolysaccharides, lipid A analogue, muramyl peptide), leukotrienes, phorbol esters, complement components, reactive oxygen species and cytokines, to name a few. In fact, production of TNF- $\alpha$ or IL- 1 during virus infection may occur both directly or indirectly (for example, as a result of cellular damage in response to virus infection or via induction by other cytokines). IFN- $\alpha$ is capable of inducing both TNF- $\alpha$ and IL-1, and crossinduction of TNF- $\alpha$ and IL- 1 has been demonstrated in many cell types (reviewed in [76]).

While information on the in vivo cytokine response to pulmonary virus infections of domestic animals is scarce, cytokines have been shown to be involved in 3 important respiratory virus infections of humans - influenza, respiratory syncytial virus (RSV) infection and rhinovirus colds. The available data from these studies are summarised here.

Influenza in humans is caused by type A influenza viruses that are antigenically related to those of swine. The infection is characterised by marked constitutional symptoms (fever, chills, muscular aching, prostration and anorexia) and respiratory signs. In susceptible individuals, the virus replicates in epithelial cells along the entire respiratory tract. Peak virus replication is associated with the degeneration of respiratory tract epithelium and excessive neutrophil infiltration. The typical influenza symptoms and pathology almost certainly involve cytokines, as demonstrated in experimental infections of human volunteers or mice. In humans, rapid peaks of IFN- $\alpha$ and IL-6 from nasal lavage fluid were followed by peaks of TNF- $\alpha$ and IL- 8 , while IL- $1 \beta$ remained undetectable [57]. Nasal IFN- $\alpha$ and IL- 6 concentrations are directly correlated with viral titres and signs of upper respiratory illness, such as runny nose and sore throat. In addition, plasma IL-6 levels are associated with both systemic and upper respiratory symptoms. Systemic cytokine levels, however, are either significantly lower than those in respiratory tract secretions or undetectable, indicating a higher local production of cytokines. Unfortunately, these human volunteer challenge studies fail to reproduce the severe lower respiratory tract disease that often results from natural influenza infections. In addition, sampling of the lower respiratory tract is not practical in humans. Until now, the association between cytokines and influenza pneumonia has been studied exclusively in mice, which are not natural influenza virus hosts. In this murine model, there is an early increase of both TNF- $\alpha$ and IL- $1599,99,131]$ in bronchoalveolar lavage fluids (BAL), and cytokines correlate with the characteristic signs of disease (lethargy, anorexia, followed by mortality) and with mononuclear cell infiltration in the lungs and gross lesion development. In a study by Hennet et al. [59], production of TNF- $\alpha /$ IL-1 was followed by that of other cytokines and inflammatory products: IL-6, granulocyte macrophage-colony stimulating factor, IFN- $\gamma$ and leukotriene B4. Thus, cytokines and mediators other than TNF- $\alpha / \mathrm{IL}-1$ may participate in the inflammatory response and their production may be induced or stimulated via TNF- $\alpha / \mathrm{IL}-1$. The role of individual cytokines during influenza in mice was assessed only recently by specific anti-cytokine strategies. Intraperitoneal 
administration of TNF antibodies at the time of influenza inoculation reduces lung lesion severity and prolongs survival by $24 \mathrm{~h}$ [99]. In IL-1 $\beta$ gene knock-out mice, influenza inoculation has a smaller effect on body temperature than in wild type mice, but anorexia and weight loss are similar [68]. Similarly, treatment with either IFN- $\alpha$ or IL- $1 \alpha$ antibodies reduces fever [71]. The finding that IFN antibodies suppress IL-1 production supports the importance of cytokine networking. Although these studies confirm the significance of cytokines in influenza pathogenesis, the effect of blocking individual cytokines was only partial and in some cases very modest. Furthermore, higher mortality rates in IL-1 $\beta$ knockout mice indicate that anti-cytokine strategies may endanger the host natural defence [68].

Respiratory syncytial virus (RSV) infections may cause severe lower respiratory tract disease, particularly in children. Epithelial cells of the upper and lower respiratory tract are the main viral target cells. Bronchiolitis, with excessive neutrophil infiltration, pneumonitis and lung emphysema are prominent histopathological features. There are few experimental data on in vivo cytokine production in RSV infection, but data from RSV patients and from in vitro studies support the involvement of multiple (pro)inflammatory cytokines in RSVinduced inflammation. In a BALB/c mouse model of RSV infection, a sharp rise in TNF- $\alpha$ and IL-1 from BAL fluid and proportionally lower serum levels of both cytokines were detected as early as one day after inoculation [58]. Disease, lung inflammatory changes and cytokine secretion were interrelated and clearly virus dose-dependent. Comparable high amounts of TNF- $\alpha$ and IL- 6 , next to IL- $1 \beta$ and IL- 8 have been found in nasal secretions and superficial mucosal biopsies in RSV-infected infants and children [80, 91]. Further evidence for a role of TNF- $\alpha$ and IL- 6 in acute RSV infections comes from a patient study in which higher IL-6: TNF- $\alpha$ ratios in nasopha- ryngeal secretions are correlated with the lower severities of the disease [61]. This finding can be explained by the negative effects of IL- 6 on TNF- $\alpha$ and IL- 1 release and resulting proinflammatory effects [110]. IL-8 is generally thought to play a major role in RSV-induced neutrophil influx and bronchiolitis, because of excessive plasma IL-8 concentrations in severely affected patients [18]. All these cytokines have also been demonstrated in cultures of macrophages [83, 127] and pulmonary epithelial cells $[7,90]$. In vitro experiments suggest that TNF- $\alpha$ and IL- 1 are the main inducers of IL-8 during RSV infection [7, 14]. One particular feature of RSV is its capacity to induce inhibitors of proinflammatory cytokine action in vitro, notably IL-1 inhibitor [105] and soluble TNF-receptor type I [7].

Human rhinoviruses are responsible for the majority of common colds. Rhinovirus infection of the nasal epithelium typically produces congestion and neutrophil infiltration and increased glandular secretions. The cytokines IL-1 $\beta$, IL- 6 and IL- 8 have been found in the nasal secretions of symptomatic humans with experimental rhinovirus colds [103, 128, 154]. These very cytokines, in addition to TNF- $\alpha$, are also induced by infection of cultured lung epithelial cells $[64,123]$. Both TNF- $\alpha$ [120] and IL-1 $\beta$ [123] have been reported to upregulate the expression of ICAM-1, the major rhinovirus receptor on epithelial cells. In this way, cytokines can possibly enhance rhinovirus replication thereby maintaining the cytokine response.

In pigs, cytokine production during pulmonary virus infections has not been studied so far. Yet, support for the involvement of early cytokines in respiratory pathology has been obtained from experimental infections with mycoplasma and bacteria. Pigs infected with Mycoplasma hyopneumoniae develop characteristic gross lung lesions and peribronchiolar lymphoid hyperplasia which are directly associated with TNF- $\alpha$, IL- 1 and IL-6 in BAL fluids $[9,10]$. After infection 
with Actinobacillus pleuropneumoniae, typical pleuropneumonic lesions were found to be related to the production of IL-1 and IL-8, while TNF- $\alpha$ was seemingly less important [11]. Field studies as well suggest a role for early cytokines in respiratory disease. TNF- $\alpha$ has been associated with an acute phase response and post-arrival disease in boars [55]. The presence of IFN- $\alpha$ in serum is considered as a possible indicator of viral infections during the first weeks after grouping together of pigs in multisource fattening herds [8].

\section{GROWING EVIDENCE FOR A ROLE OF CYTOKINES IN PULMONARY VIRUS INFECTIONS OF PIGS}

The clinical manifestations of a given respiratory virus infection in pigs will depend both on the pathogenicity of the virus and on the presence and nature of concurrent respiratory infections. At the pathogenetic level, the excessive production of early cytokines can theoretically switch the balance from subclinical to disease. To begin to test this hypothesis, we performed a series of experimental studies in which we analysed and compared the clinical and lung inflammatory response to different viruses and virus combinations. In these studies, we especially tried to find correlations between the cytokine patterns and the associated pathogenetic features. All experiments were performed under strictly gnotobiotic conditions, in caesarean-derived and colostrumdeprived pigs. Between 3 and 4 weeks of age, the pigs were administered the highest possible dose of the respective virus(es) $\left(10^{6.0}\right.$ to $10^{7.5} \mathrm{ID}_{50}$ per pig) by a standardised intratracheal inoculation method. Mockinoculated control pigs were included in each experiment. The pigs were clinically monitored and euthanatised during the acute stage of infection. Lung inspections, virologic and histopathologic examinations were performed. Total cell numbers and percent- ages of neutrophils in bronchoalveolar lavage (BAL) fluids were determined and cell-free lavage fluids were assayed for cytokines by bioassays.

\subsection{Cytokine profiles correlate with intrinsic pathogenicity of respiratory viruses}

In this first series of studies, we examined whether SIV, PRCV and PRRSV differ in their ability to induce lung proinflammatory cytokine secretion and whether different cytokine profiles can be linked to different clinical and pathogenetic features. Different times of euthanasia were selected for each virus infection, because of their known differences in replication kinetics. Figure 1 compares clinicopathological and cytokine responses during SIV, PRCV and PRRSV infection. These results have been described in detail elsewhere [143].

The inoculation with an H1N1-subtype SIV was followed by typical systemic and respiratory signs (depression, anorexia, shivering, tachypnoea, dyspnoea and coughing) and massive lung virus replication within 18 to $24 \mathrm{~h}$. At that time, neutrophils, which were virtually absent in virus-negative control pigs, were the predominant cell type in BAL fluids and there was excessive lung epithelial desquamation and complete obstruction of many bronchi and bronchioli with neutrophils and other cells. Gross lung consolidation of approximately $20-40 \%$ of the lungs developed 2 and 3 days after inoculation. The secretion of all 3 examined cytokines was temporally correlated with the development of disease and lung inflammation, as well as with virus replication. IFN- $\alpha$ was found in particularly high levels. TNF- $\alpha$ and IL- 1 titres were proportionally lower, but substantial in comparison with bioactive amounts of these cytokines in other in vivo studies. As clinical symptoms and lung inflammation subsided, IFN- $\alpha$ levels diminished and TNF- $\alpha$ and IL-1 became undetectable. Interestingly, 


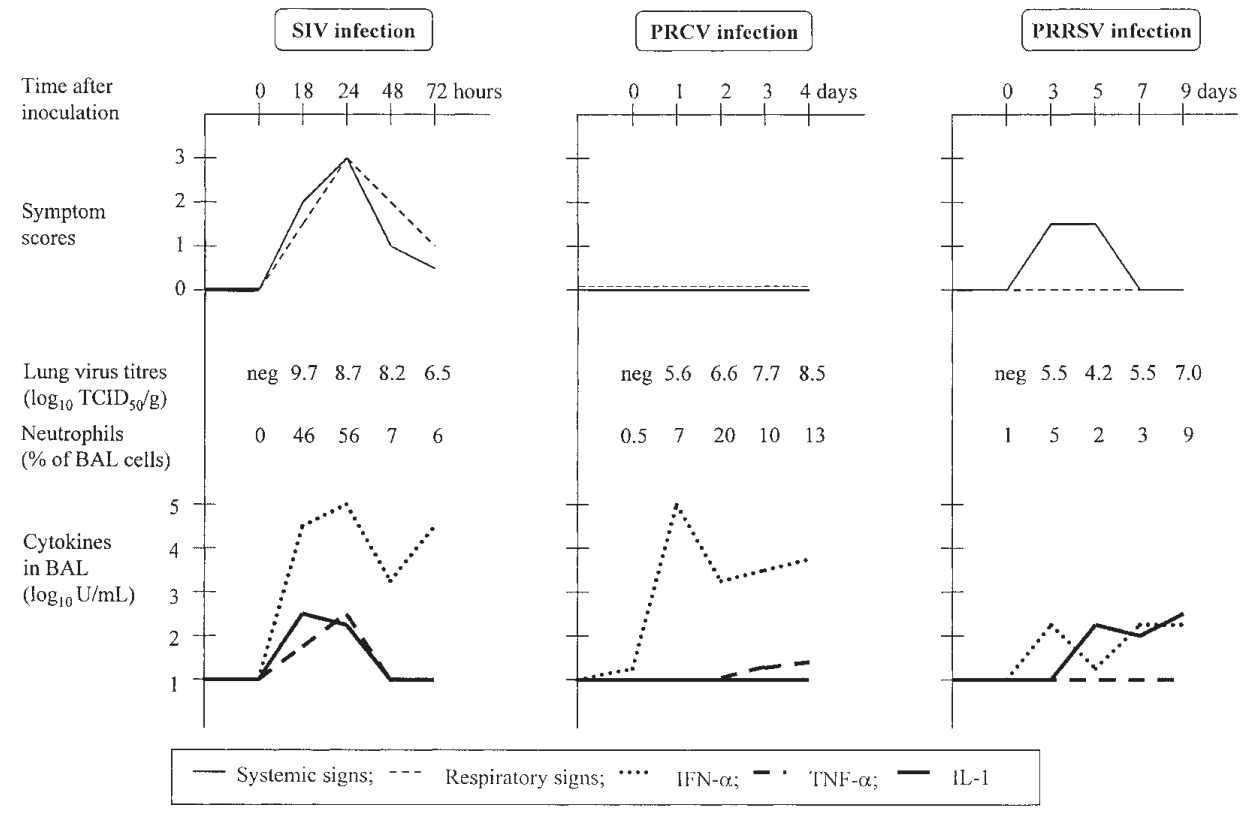

Figure 1. Comparative profiles of clinical signs, lung virus titres, neutrophils and cytokines in bronchoalveolar lavage (BAL) fluids after intratracheal inoculation with swine influenza virus (SIV), porcine respiratory coronavirus (PRCV) or porcine reproductive-respiratory syndrome virus (PRRSV) (details in [143]).

individual cytokine levels as well correlated largely with clinical severities and lung pathology, as demonstrated earlier in another study [142]. Though similar cytokine profiles have been demonstrated in BAL fluids of mice and in nasal lavage fluids of man during experimental influenza virus infections, this was the first demonstration of cytokines in the lungs of a natural influenza virus host. Moreover, our findings strongly argue for a role of these cytokines in typical flu symptoms and pneumonia.

PRCV infection was entirely asymptomatic, despite relatively high amounts of infectious virus production. Neutrophil infiltration occurred, but not to the degree seen in SIV infection. The histopathological changes much resembled those described in previous experimental studies [35, 92] and mainly consisted of a mild multifocal airway epithelial necrosis and infiltration with macrophages, and a few neutrophils. In spite of the subclinical course of the infection, gross lung consolidation involved up to $34 \%$ of the lungs at 4 DPI and as such equalled the gross pathology of an SIV infection. IFN- $\alpha$ was detected at high levels, but TNF- $\alpha$ was negligible and IL- 1 undetectable. Thus, though the presence of interferons has been associated with fevers, chills and malaise in acute viral infections, the present data implicate that high levels of IFN- $\alpha$ as such are insufficient to produce disease.

PRRSV infection induced a transient anorexia and lethargy, without obvious respiratory signs. BAL neutrophil percentages remained low, but there was a massive infiltration of the lungs with mononuclear cells and macrophages resulting in an up to 5fold increase of total BAL cells at 7-10 DPI, and marked thickening of alveolar septa on 
histopathology. In many respects, PRRSV did not behave like a classical respiratory virus. Unlike SIV or PRCV, PRRSV infection induced no microscopic lung epithelial damage and minimal consolidation lesions. Instead, a failure to collapse, a mild interlobular oedema and small multifocal areas of atelectasis were the main necropsy findings. IFN- $\alpha$ titres were at least 100 times lower than those found during SIV or PRCV infection and TNF- $\alpha$ was negative, but there was considerable production of IL-1. The prolonged secretion of IL-1 during this infection prompts the question as to why cytokine production is rapidly shut down during some infections, such as SIV, and not during others. The exact role of IL-1 in the pathogenesis of PRRSV infection is uncertain. There is the possibility that IL-1 contributes to the systemic symptoms observed and to the mononuclear cell infiltration of the lung. Indeed, localised production of IL-1 can induce fever and anorexia [60], and IL-1 is one of the main stimuli for the production of monocyte-attracting chemokines [153].

Taken together, these studies document differential production of early cytokines during different respiratory virus infections. These differences may explain exactly why SIV is the single most important respiratory virus infection of swine, and why PRCV or PRRSV tend to cause subclinical infections if uncomplicated. Because of the coordinate and excessive production of IFN- $\alpha$, TNF- $\alpha$ and IL-1 during SIV infection, these cytokines will most probably act synergistically to induce lung inflammation and "flulike" symptoms. Additional support for this hypothesis comes from the demonstration of a very similar BAL cytokine profile in typical natural cases of SI. Conversely, the lack of such a "cytokine triad" during PRCV or PRRSV infection may in part account for the mild respiratory pathology and the absence of clinical disease.

So far, we have concentrated on the acute inflammatory response to respiratory virus infections. The subacute and resolution phase also greatly differs with SIV, PRCV and PRRSV. That is, the influenza virus elicits extremely rapid and efficient immune responses and complete virus elimination from the lungs occurs within 1 week post initial virus exposure. Infection with PRCV or PRRSV, however, lasts for an approximate 12 and 28 days respectively. Several data support the hypothesis that the successful immune response against SIV may be related to the quick and efficient production of multiple cytokines. IFN- $\alpha$, TNF- $\alpha$ and IL-1, in addition to modulating nonspecific immune responses, can also participate in the specific immune response to infection (reviewed in [62, 125]). Furthermore, several "late" cytokines with highly specific immune-regulatory properties have already been demonstrated in the mouse model [13].

\subsection{Dual infections with respiratory viruses}

It is a classic hypothesis that virus infections of the lungs open the door for bacteria and thereby facilitate disease. It is less well known that dual or multiple infections with respiratory viruses in itself occur very often in the field [140]. Combined infections with PRRSV and other enzootic viruses, such as PRCV, have been regularly diagnosed and have been linked with respiratory disease problems in some instances $[50,65]$. In previous experimental studies in conventional pigs, we have further demonstrated the clinical significance of combined PRRSVPRCV infections [141]. Pigs inoculated with PRRSV and then 3 days later with PRCV developed a 9 day lasting fever with tachypnoea, dyspnoea, productive coughing and significant growth retardation. The present gnotobiotic pig studies were undertaken in an attempt to unravel the pathogenesis of such infections. We set out to test the hypothesis that PRRSV primes production of IL- 1 and TNF- $\alpha$ in response to a subsequent PRCV infection and thereby promotes clinical disease, based on the cytokine and 



Figure 2. Interferon- $\alpha$ (shaded bars), tumour necrosis factor- $\alpha$ (open bars) and interleukin-1 (dark bars) titres in bronchoalveolar lavage fluids after intratracheal inoculation with PRRSV or PRCV only or with the PRRSV-PRCV combination at 3- and 7-day intervals. Data of one individual pig are given at each time point. Titres higher than $10000 \mathrm{U} \cdot \mathrm{mL}^{-1}$ are indicated by //. Pigs with clinical disease at euthanasia are indicated by *.

clinical profiles of the single PRRSV and PRCV infections. As shown in Figure 2, the pigs were inoculated with PRRSV first and then, 3 or 7 days later, with PRCV. The dually inoculated pigs were sequentially killed between 2 and 5 days after PRCV and compared with singly PRRSV- and PRCVinoculated controls. 
The clinical outcomes in these gnotobiotic pig studies differed substantially from those in conventional pigs. Generally speaking, the disease was milder and the morbidity rates were lower under gnotobiotic conditions, and only 3 of the total 10 PRRSVPRCV infected pigs were seen with marked general disease and tachypnoea. Given the fact that monocytes and macrophages are pre-eminent producer cells of TNF- $\alpha$ and IL-1, one could speculate that the increased cell numbers following PRRSV infection predispose for an enhanced cytokine release and resulting dramatic neutrophil influx after a second infection. This hypothesis, however, had to be rejected. Both in the 3 dayand 7 day-interval groups, BAL cell numbers and composition were quite similar to those after single PRRSV infection. Proportionally, neutrophil infiltration was even lower after dual than after single PRCV inoculation ( $\leq 8 \%$ in dually infected pigs versus $\leq 20 \%$ in singly PRCV-infected pigs), but due to increased total BAL cells in the PRRSV-PRCV groups, absolute neutrophil counts were comparable. Histopathological examination of the lungs revealed the mononuclear cell infiltration characteristic of PRRSV infection in addition to the typical bronchointerstitial pneumonia of PRCV. Similarly, macroscopic lung lesion scores resembled a combination of the effects of both single virus infections, rather than a potentiation of one virus infection on another. This also holds true for cytokine production: TNF- $\alpha$ was undetectable, and IFN- $\alpha$ and IL- 1 were detected at levels similar to those during single PRCV and PRRSV infections respectively. A closer look at individual cytokine titres of the dually infected pigs, however, cannot exclude some involvement of cytokines in disease. Two of the 3 severely affected pigs, one from each group, were killed within a few hours after the appearance of symptoms, 3 days after PRCV, at the presumed peak of the disease. These very pigs had the highest amounts of IFN- $\alpha\left(8436-19168 \mathrm{U} \cdot \mathrm{mL}^{-1}\right)$ and IL-1 (126-190 U. $\left.\mathrm{mL}^{-1}\right)$ within their respective groups. Both cytokines share the ability to produce fever, lethargy, somnolence and anorexia; additive and synergistic interactions theoretically occur between them at several levels [15]. It is thus plausible that the combination of IFN- $\alpha$ and IL-1 somehow contributes to the systemic signs of the dual PRRSV-PRCV infection.

Apart from dual PRRSV-PRCV infections, we also performed dual infections with PRRSV followed by SIV. As already mentioned, the uncomplicated SIV infection is frequently subclinical, and the combination of PRRSV and SIV has also been linked with multi-infectious respiratory disease in the field [50]. It is important to note that we chose to use an aerosol inoculation method for experimental PRRSV-SIV inoculations. This method was previously shown to reproduce a clinically mild SIV infection, with approximately 100-fold lower virus titres and much milder lung pathology than after intratracheal inoculation. The present study additionally revealed that proinflammatory cytokine levels are unremarkable after aerosol SIV inoculation. These data further substantiate the notion that rapid and massive replication of SIV contributes to the induction of all 3 cytokines and that cytokine production is implicated in the disease. As for the dual PRRSV-SIV infection, our findings were remarkably similar to those of the PRRSV-PRCV infection. Again, disease severities were milder and mortality rates (20-25\%) lower in gnotobiotic pigs than in previous conventional pig studies. The pathological and cytokine picture of the lung resembled a combination of the effects of both single virus infections, rather than a potentiation of one virus infection on another. IFN- $\alpha$ and IL- 1 were the only cytokines produced, and TNF- $\alpha$ was missing in all pigs. These data were not statistically significant, despite a tendency towards higher IL-1 titres in severely affected pigs.

The conclusive message from these dual viral infection studies is that prior infection with PRRSV fails to potentiate cytokine production in response to a subsequent viral 
infection. The poor cytokine response is in agreement with the overall mild clinical course of the pure dual viral infection. This does not mean that dual infections with respiratory viruses are unimportant in the etiology of PRDC. In the field, interactions between PRRSV and one single additional pathogen are more the exception than the rule, and multifactorial respiratory disease usually involves interactions of multiple pathogens or factors. Besides, the clinical and economic impact of dual viral infections has been demonstrated in conventional pig studies [141], under conditions that more closely mimic the field situation. It was learned, however, that the final clinical outcome of such infections is always unpredictable and dependent on factors that are difficult to discover or reproduce experimentally. For this reason, we decided to search for a better model to reproduce and study the pathogenesis of PRDC.

\subsection{Interactions between respiratory viruses and bacterial lipopolysaccharides}

Endotoxin or lipopolysaccharide (LPS) is a component of the outer membrane of Gram-negative bacteria. Endotoxins occur at relatively high concentrations in the respirable fraction of dust in swine confinement units [108] and they are released locally in the lungs during pulmonary infections with Gram-negative bacteria. In man and several animal species, endotoxin exposure can induce a marked infiltration of the lungs with neutrophils and macrophages, decreased lung functions and chronic coughing [129, 130, 145]. Many of the biological effects of LPS are mediated via the release of TNF- $\alpha$ and IL-1 [129, 146]. Nearly all endotoxin effects are strictly dose-related, and lower endotoxin levels are insufficient for cytokine induction and disease to occur [82, 129].

The potential interactions between viruses and endotoxins in the respiratory tract of domestic animals are unexplored. We have recently performed experimental combined inoculations of pigs with PRCV followed by LPS from E. coli 0111:B4 (described in detail in [144]). One of the important reasons for the choice of this combination, was that the intratracheal inoculation with either PRCV alone or relatively low doses $\left(20 \mu \mathrm{g} \cdot \mathrm{kg}^{-1}\right)$ of LPS alone induced no clinical disease and negligible production of TNF- $\alpha$ or IL-1. Also, combined inoculation with a virus and an agent that does not multiply, such as LPS, may avoid the variability resulting from interference of a first virus with replication of a second virus. In contrast to the respective single agent inoculations, dual inoculations with PRCV followed $24 \mathrm{~h}$ later by LPS resulted in marked laboured breathing, dullness and loss of appetite during the first $10-12 \mathrm{~h}$ after LPS. Unlike in dual infections with 2 viruses, severe disease was seen in all PRCV-LPS pigs. A significant timedependent increase of both TNF- $\alpha$ and IL-1 was noted, but TNF- $\alpha$ correlated better with the development of respiratory symptoms than IL-1. In spite of abundant neutrophil infiltration in the lungs of PRCV-LPS inoculated pigs, neutrophils did not seem to play a major role in PRCV-LPS induced illness. Firstly, neutrophil infiltration occurred to the same extent in PRCV-LPS and singly LPSinoculated pigs. Secondly, neutrophils persisted for longer time periods after LPS than the clinical signs. In our view, this provides an excellent example of the "redundancy" and "pleiotropy" of the actions of TNF- $\alpha$ or other cytokines. There are indeed few biological responses that are mediated by only one cytokine. Accumulation of neutrophils in the lung, though often due to TNF- $\alpha$ production, is not unique to this cytokine and can result from the actions of several other cytokines/chemokines, or even from the direct actions of LPS on pulmonary endothelium and/or neutrophils. Conversely, TNF- $\alpha$ can exert many effects other than neutrophil sequestration in the lungs: activation of phagocytic cells, bronchial hyperresponsiveness or bronchoconstriction represent just a few examples. It is an attractive 
hypothesis that the pathogenesis of PRCVLPS induced respiratory disease is in part mediated by these rather functional effects of TNF- $\alpha$.

\subsection{Final thoughts}

In conclusion, we have been able to establish 2 experimental models of virusinduced respiratory disease in pigs: the single SIV inoculation and the combined PRCV-LPS inoculation. Proinflammatory cytokines likely play a critical role in both clinical entities and they may provide a clue as to why clinically manifest respiratory disease develops in these infection models but not in others. This does not mean, however, that the exact cytokines involved and their actions are identical in both respiratory disease conditions. In fact, there is preliminary evidence as to the contrary. The precise contributions of the cytokines found here have to be further documented in both settings. Given the fact that TNF- $\alpha$ and IL- 1 are potent stimuli for production of IL- 6 and a series of chemokines [153], it is only reasonable to assume that cytokines other than those tested here also play a role. Besides, IL- 6 and IL- 8 have been detected in influenza infected mice and human volunteers respectively $[57,59]$, and LPS has been shown to induce almost any cytokine. The contributions of the direct effects of virus and LPS on lung cells may be equally important. It has been accepted for a long time that typical influenza pathology results to some extent from the direct cytopathic effects of the virus on the respiratory epithelium. LPS as well can have direct damaging effects on epithelia and endothelia [22, 111] and can induce adhesion molecule expression in a cytokine-independent way.

Our virus-cytokine studies in pigs have been merely descriptive, but they did raise several more fundamental questions. Which proteins or genes of the influenza virus are responsible for cytokine induction? How do viruses prime cells for an enhanced cytokine response to a second stimulus? Are cytokines produced by virus-infected or by bystander cells? Can neutrophils in the inflammatory exudate affect cytokine production? To resolve some of these questions, we are now working to detect the cellular source of cytokines in virus-infected lungs by immunohistochemistry and in situ hybridisation. These techniques will allow us to investigate the spatial relationship between cytokine-producing cells on the one hand and virus-infected and inflammatory cells on the other. Furthermore, they will help us to develop in vitro models resembling the in vivo situation as closely as possible, and to study the basic mechanisms of cytokine induction by viruses.

\section{EPILOGUE}

Why study cytokine production during respiratory infections of swine? Will we ever use (anti)cytokine treatments in the control of respiratory disease in farm animals? Unfortunately, the potential use of antibodies against proinflammatory cytokines, or cytokines with anti-inflammatory properties, or even cytokine receptors or their antagonists has a number of limitations. For example, it is not practical to deliver such molecules locally in the deeper lung, as would be required to modulate production or local actions of the cytokine mediating (respiratory) disease. Another difficulty is the timing of (anti)cytokine administration. Preventive application, which is problematic under field conditions, is definitely more successful than therapeutic administration. A major problem is that suppression of those (pro)inflammatory cytokines whose overproduction can be detrimental has shown to compromise host defence mechanisms in many instances. Indeed, the effects of these cytokines, such as changes in vascular permeability, neutrophil chemotaxis, phagocyte activation and hyperthermia, initially serve to eliminate pathogens and help to restore normal body functions. The balance 
between the beneficial and detrimental effects of the inflammatory and acute phase reactions are extremely delicate. Additionally, given the redundancy of cytokine actions, it would be unrealistic to expect that inhibition of one single cytokine will have a profound effect on such a complex process as inflammation. Finally, synthetic cytokines or their inhibitors are still too expensive to allow their large-scale use in domestic animals. Still, experimental cytokine studies are useful for at least two reasons. Firstly, non-steroidal anti-inflammatory drugs are widely used in the treatment of respiratory disease, while their effects on the pathophysiology of disease are only very rudimentarily known. Studies of the specific effects of different categories of these drugs on cytokine profiles and associated pathological features will help us to develop more rational treatments. At the same time, such studies will give further insights into the roles of cytokines in the disease processes. Secondly, the determinants of respiratory virus pathogenicity remain largely unknown. Knowledge of the pathways of cytokine induction by viruses can reveal important new information in this respect.

\section{ACKNOWLEDGEMENTS}

We thank Prof. Dr. M. Pensaert for asking the questions that led to virus-cytokine studies in pigs, and Lieve Sys for invaluable help with cytokine detection methods. The research described here was financially supported by the Belgian Ministry of Agriculture. Kristien Van Reeth is a postdoctoral fellow of the Fund for Scientific Research - Flanders (FWO - Vlaanderen).

\section{REFERENCES}

[1] Adler K.B., Fischer B.M., Wright D.T., Cohn L.A., Becker S., Interactions between respiratory epithelial cells and cytokines: relationships to lung inflammation, Ann. N.Y. Acad. Sci. 725 (1994) 128-145.

[2] Albina E., Leforban Y., Baron T., Plana Duran J., Vannier P., An enzyme linked immunosorbent assay (ELISA) for the detection of antibodies to the porcine reproductive and respiratory syndrome (PRRSV) virus, Ann. Rech. Vet. 23 (1992) 167-176.

[3] Albina E., Madec F., Cariolet R., Torrison J., Immune response and persistence of the porcine reproductive and respiratory syndrome virus in infected pigs and farm units, Vet. Rec. 134 (1994) 567-573.

[4] Albina E., Kobisch R., Cariolet P., Morvan P., Kéranflec'h A., Beaurepaire B., Hutet E., Labbé A., Le syndrome dysgénésique et respiratoire du porc (SDRP): Étude expérimentale des effets de l'infection sur la réponse immunitaire et la résistance aux infections Aujeszky et Mycoplasma hyopneumoniae chez le porc en croissance, Journ. Rech. Porcine Fr. 27 (1995) 107-116.

[5] Albina E., Porcine reproductive and respiratory syndrome: ten years of experience (1986-1996) with this undesirable viral infection (in French), Vet. Res. 28 (1997) 305-352.

[6] Albina E., Piriou L., Hutet E., Cariolet R., L'Hospitalier R., Immune responses in pigs infected with porcine reproductive and respiratory syndrome virus (PRRSV), Vet. Immunol. Immunopathol. 61 (1998) 49-66.

[7] Arnold R., Humbert B., Werchan H., Gallati H., Konig W., Interleukin-8, interleukin-6 and soluble tumour necrosis factor receptor type 1 release from a human pulmonary epithelial cell line (A 549) exposed to respiratory syncytial virus, Immunology 82 (1994) 126-133.

[8] Artursson K., Wallgren P., Alm G.V., Appearance of interferon- $\alpha$ in serum and signs of reduced immune function in pigs after transport and installation in a fattening farm, Vet. Immunol. Immunopathol. 23 (1989) 345-353.

[9] Asai T., Okada M., Ono M., Irisawa T., Mori Y., Yokomizo Y., Sato S., Increased levels of tumor necrosis factor and interleukin 1 in bronchoalveolar lavage fluids from pigs infected with Mycoplasma hyopneumoniae, Vet. Immunol. Immunopathol. 38 (1993) 253-260.

[10] Asai T., Okada M., Ono M., Mori Y., Yokimizo Y., Sato S., Detection of interleukin-6 and prostaglandin $\mathrm{E}_{2}$ in bronchoalveolar lavage fluids of pigs experimentally infected with Mycoplasma hyopneumoniae, Vet. Immunol. Immunopathol. 44 (1994) 97-102.

[11] Baarsch M.J., Scamurra R.W., Burger K., Foss D.L., Maheswaran S.K., Murtaugh M.P., Inflammatory cytokine expression in swine experimentally infected with Actinobacillus pleuropneumoniae, Infect. Immun. 63 (1995) 3587-3594.

[12] Baron T., Albina E., Leforban Y., Madec F., Guilmoto H., Plana Duran J., Vannier P., Report on the first outbreaks of the porcine reproductive and respiratory syndrome (PRRS) in France. Diagnosis and viral isolation, Ann. Rech. Vet. 23 (1992) 161-166. 
[13] Baumgarth N., Brown L., Jackson D., Kelso A., Novel features of the respiratory tract T-cell response to influenza virus infection: lung $\mathrm{T}$ cells increase expression of $\gamma$-interferon mRNA in vivo and maintain high levels of mRNA expression for interleukin-5 (IL-5) and IL-10, J. Virol. 68 (1994) 7575-7581.

[14] Becker S., Koren H.S., Henke D.C., Interleukin8 expression in normal nasal epithelium and its modulation by infection with respiratory syncytial virus and cytokines tumor necrosis factor, interleukin-1 and interleukin-6, Am. J. Respir. Cell. Mol. Biol. 8 (1993) 20-27.

[15] Belardelli F., Gabriele L., Proietti E., Sesteli P., Peretti M., Rozera C., Gresser I., Synergistic anti-tumor effects of combined IL-1/IFN- $\alpha / \beta$ therapy in mice injected with metastatic Friend erythroleukemia cells, Int. J. Cancer 49 (1991) 274-278.

[16] Bielefeldt-Ohmann H., Campos M., Snider M., Rapin N., Beskorwayne T., Popowyck Y., Lawman M.J.P., Rossi A., Babiuk L.A., Effect of chronic administration of recombinant bovine tumor necrosis factor to cattle, Vet. Pathol. 26 (1989) 462-472.

[17] Bilodeau R., Archambault D., Vezina S.A., Fournier M., Dea S., Persistence of porcine reproductive and respiratory syndrome virus infection in a swine operation, Can. J. Vet. Res. 58 (1994) 291-298.

[18] Biswas S., Friedland J.S., Remick D.G., Davies E.G., Sharland M., Elevated plasma interleukin8 in respiratory syncytial virus bronchiolitis, Pediatr. Infect. Dis. J. 14 (1995) 919.

[19] Bittleman D.B., Casale B.C., Interleukin-8 mediates interleukin-1alpha-induced neutrophil transcellular migration, Am. J. Respir. Cell. Mol. Biol. (1995) 323-329.

[20] Blecha F., Reddy D.N., Chitko-McKown C.G., McVey D.S., Chengappa M.M., Goodband R.D., Nellsen J.L., Influence of recombinant bovine interleukin- $1 \alpha$ and interleukin- 2 in pigs vaccinated and challenged with Streptococcus suis, Vet. Immunol. Immunopathol. 44 (1995) 329346.

[21] Bourgueil E., Hutet E., Cariolet R., Vannier P., Experimental infection of pigs with the porcine respiratory coronavirus (PRCV): measure of viral excretion, Vet. Microbiol. 31 (1992) 1118.

[22] Breider M.A., Kumar S., Corstvet R.E., Bovine pulmonary endothelial cell damage mediated by Pasteurella haemolytica pathogenic factors, Infect. Immun. 58 (1990) 1671.

[23] Brown I.H., Done S.H., Spencer Y.I., Cooley W.A., Harris P.A., Alexander D.J., Pathogenicity of a swine influenza H1N1 virus antigenically distinguishable from classical and European strains, Vet. Rec. 132 (1993) 598-602.
[24] Brown I.H., Chakraverty P., Harris P.A., Alexander D.J., Disease outbreaks in pigs in Great Britain due to an influenza A virus of $\mathrm{H} 1 \mathrm{~N} 2 \mathrm{sub}-$ type, Vet. Rec. 136 (1995) 328-329.

[25] Bry K., Lappalainen U., Hallman M., Cytokines and production of surfactant components, Sem. Perionatol. 20 (1996) 194-205.

[26] Caldwell J., Emerson S.G., Interleukin-1 alpha upregulates tumor necrosis factor receptors expressed by a human bone marrow stromal cell strain: implications for cytokine redundancy and synergy, Blood 86 (1995) 3364-3372.

[27] Campos M., Bielefeldt-Ohmann H., Hughes G., Babiuk L.A., Lawman M.P.J., Studies on the in vitro biological activities of recombinant tumor necrosis factor (rBo TNF) alpha. Synergistic antiviral efficacy of rBoTNF alpha, recombinant bovine interferon- $\gamma$ (rBo IFN $\gamma$ ) and their combination, Antiviral Res. 10 (1988) 71-81.

[28] Chakrabarti D., Hultgren B., Stewart T.A., IFN- $\alpha$ induces autoimmune $T$ cells through the induction of intracellular adhesion molecule- 1 and B7.2, J. Immunol. 157 (1996) 522-528.

[29] Chiang Y.W., Murata H., Roth J.A., Activation of bovine neutrophils by recombinant bovine tumor necrosis factor- $\alpha$, Vet. Immunol. Immunopathol. 29 (1991) 329-338.

[30] Cho S.H., Freese W.R., Yoon I.J., Trigo A.V., Joo H.S., Seroprevalence of indirect fluorescent antibody to porcine reproductive and respiratory syndrome virus in selected swine herds, J. Vet. Diagn. Invest. 5 (1993) 259-260.

[31] Coe N.E., Frank D.E., Roth J.A., Effect of recombinant human cytokines on porcine neutrophil function, Vet. Immunol. Immunopathol. 37 (1993) 39-47.

[32] Collins J.E., Benfield D.A., Christianson W.T., Harris L., Hennings J.C., Shaw D.P., Goyal S.M., McCullough S., Morrison R.B., Joo H.S., Isolation of swine infertility and respiratory syndrome virus (isolate ATCC VR-2332) in North America and experimental reproduction of the disease in gnotobiotic pigs, J. Vet. Diagn. Invest. 4 (1992) 117-126.

[33] Conn C.A., Mcclellan J.L., Maassab H.F., Smitka C.W., Majde J.A., Kluger M.J., Cytokines and the acute phase response to influenza virus in mice, Am. J. Physiol. 268 (1995) R78-84.

[34] Cooper V.L., Doster A.R., Hesse R.A., Harris N.B., Porcine reproductive and respiratory syndrome: NEB-1 PRRSV infection did not potentiate bacterial pathogens, J. Vet. Diagn. Invest. 7 (1995) 313-320.

[35] Cox E., Hooyberghs J., Pensaert M.B., Sites of replication of a porcine respiratory coronavirus related to transmissible gastroenteritis virus, Res. Vet. Sci. 48 (1990) 165-169.

[36] Cox E., Pensaert M., Hooyberghs J., Van Deun K., Sites of replication of a porcine respiratory 
coronavirus in 5-week-old pigs with or without maternal antibodies, in: Cavanagh D., Brown T.D.K. (Ed.), Coronaviruses and their diseases, Plenum Press, New York, 1990, pp. 429-433.

[37] Dinarello C.A., The proinflammatory cytokines interleukin-1 and tumor necrosis factor and treatment of the septic shock syndrome, J. Infect. Dis. 163 (1991) 1177-1184.

[38] Dinarello C.A., Cannon J.G., Wolff S.M., Bernheim H.A., Beutler B., Cerami A., Figari I.S., Palladino A., O'Connor J.V., Tumor necrosis factor (cachectin) is an endogenous pyrogen and induces production of interleukin 1, J. Exp. Med. 163 (1986) 1433-1450

[39] Duan X., Nauwynck H.J., Pensaert M.B., Virus quantification and identification of cellular targets in the lungs and lymphoid tissues of pigs at different time intervals after inoculation with porcine reproductive and respiratory syndrome virus (PRRSV), Vet. Microbiol. 56 (1997) 9-19.

[40] Duret C., Brun A., Guilmoto H., Dauvergne M., Isolement, identification et pouvoir pathogène chez le porc d'un coronavirus apparenté au virus de la gastro-entérite transmissible, Recl. Méd. Vét. 164 (1988) 221-226.

[41] Elbers A.R.W., Tielen M.J.M., Cromwijk W.A.J., Hunneman W.A., Sero-epidemiological screening of pig sera collected at the slaughterhouse to detect herds infected with Aujeszky's disease virus, porcine influenza virus and Actinobacillus (Haemophilus) pleuropneumoniae in the framework of an integrated quality control (IQC) system, Vet. Q. 12 (1990) 221-230.

[42] Endo T., Uchida Y., Matsumota H., Suzuki N., Nomura A., Hirata F., Hasegawa S., Regulation of endothelin-1 synthesis in cultured guinea pig airway epithelial cells by various cytokines, Biochem. Biophys. Res. Commun. 186 (1992) 1594-1599.

[43] Galina L., Pijoan C., Sitjar M., Christianson W.T., Rossow K., Collins J.E., Interaction between Streptococcus suis serotype 2 and porcine reproductive and respiratory syndrome virus in specific pathogen-free piglets, Vet. Rec. 134 (1994) 60-64.

[44] Godson D.L., Baca Estrada M.E., Van Kessel A.G., Hughes H.P., Morsy M.A., Van Donkersgoed J., Harland R.J., Shuster D.E., Daley M.J., Babiuk L.A., Regulation of bovine acute phase responses by recombinant interleukin-1 beta, Can. J. Vet. Res. 59 (1995) 249-255.

[45] Green J.A., Charette R.P., Yeh T.J., Smith C.B., Presence of interferon in acute and convalescent phase sera in humans with influenza or and influenza-like illness of undetermined etiology, J. Infect. Dis. 145 (1982) 837-841.

[46] Griebel P.J., Qualtier L., Davis W.C., Gee A., Bielefeldt-Ohmann H., Lawman M.J.P., Babiuk L.A., T lymphocyte population dynamics and function following a primary bovine herpesvirus type-1 infection, Viral Immunol. 1 (1987) 287304.

[47] Groschup M.H., Brun A., Haas B., Serological studies on the potential synergism of porcine reproductive and respiratory syndrome virus and influenza-, corona- and paramyxoviruses in the induction of respiratory symptoms in swine, $\mathrm{J}$. Vet. Med. B 40 (1993) 681-689.

[48] Haesebrouck F., Biront P., Pensaert M.B., Leunen J., Epizootics of respiratory tract disease in swine in Belgium due to H3N2 influenza virus and experimental reproduction of disease, Am. J. Vet. Res. 46 (1985) 1926-1928.

[49] Haesebrouck F., Pensaert M.B., Effect of intratracheal challenge of fattening pigs previously immunized with an inactivated influenza H1N1 vaccine, Vet. Microbiol. 11 (1986) 239-249.

[50] Halbur P.G., Paul P.S., Vaughn E.M., Andrews J.J., Experimental reproduction of pneumonia in gnotobiotic pigs with porcine respiratory coronavirus isolate AR310, J. Vet. Diagn. Invest. 5 (1993) 184-188.

[51] Halbur P.G., Paul P.S., Vaughn, E.M., Virulent porcine respiratory coronavirus isolates exist in the United States, in: Proc. 14th Congress Int. Pig Vet. Soc., Bangkok, Thailand (1994) 70.

[52] Halbur P.G., Paul P.S., Frey M.L., Landgraf J., Eernisse K., Meng X.J., Lum M.A., Andrews J.J., Rathje J.A., Comparison of the pathogenicity of two US porcine reproductive and respiratory syndrome virus isolates with that of the Lelystad virus, Vet. Pathol. 32 (1995) 648-660.

[53] Halbur P.G., Paul P.S., Meng X.J., Lum M.A., Andrews J.J., Rathje J.A., Comparative pathogenicity of nine US porcine reproductive and respiratory syndrome virus (PRRS) isolates in a five-week-old caesarean-derived, colostrumdeprived pig model, J. Vet. Diagn. Invest. 8 (1996) 11-20

[54] Halbur P.G., Paul P.S., Frey M.L. Landgraf J., Eernisse K., Meng X.J., Andrews J.J., Lum M.A., Rathje J.A., Comparison of the antigen distribution of two US porcine reproductive and respiratory syndrome virus isolates with that of the Lelystad virus, Vet. Pathol. 33 (1996) 159170 .

[55] Harding J.C., Baarsch M.J., Murtaugh M.P., Association of tumour necrosis factor and acute phase reactant changes with post arrival disease in swine, J. Vet. Med. B 44 (1997) 405-413.

[56] Hashimoto M., Influence of cytokines on ICAM-1 expression and soluble ICAM-1 production by human endothelial cells, Fukuoka Igaku Zasshi 85 (1994) 178-186.

[57] Hayden F.G., Fritz R., Lobo M.C., Alvord W., Strober W., Straus S. E., Local and systemic cytokine responses during experimental human influenza A virus infection. Relation to symptom formation and host defense, J. Clin. Invest. 105 (1998) 643-649. 
[58] Hayes P.J., Scott R., Weeler J., In vivo production of tumour necrosis factor- $\alpha$ and interleukin6 in BALB/c mice inoculated intranasally with a high dose of respiratory syncytial virus, J. Med. Virol. 42 (1994) 323-329.

[59] Hennet T., Ziltener H.J., Frei K., Peterhans E., A kinetic study of immune mediators in the lungs of mice infected with influenza A virus, J. Immunol. 149 (1992) 932-939.

[60] Hill A.G., Siegel J., Rounds J., Wilmore D.W., Metabolic responses to interleukin-1: centrally and peripherally mediated, Ann. Surg. 225 (1997) 246-251.

[61] Hornsleth A., Klug B., Nir M., Johansen J., Hansen K.S., Christensen L.S., Larsen L.B., Tech S., Severity of respiratory syncytial virus disease related to type and genotype of virus and to cytokine values in nasopharyngeal secretions, Pediatr. Infect. Dis. J. 17 (1998) 1114-1121.

[62] Hughes H.P.A., Babiuk L.A., Potentiation of the immune response by cytokines, in: Myers M.J., Murtaugh M.P. (Ed.), Cytokines in Animal Health and Disease, Marcel Dekker, New York, 1995, pp. 183-202.

[63] Imamura S., Matsukawa A., Ohkawara S., Kagayama M., Yoshinaga M., Involvement of tumor necrosis factor- $\alpha$, interleukin- $1 \beta$, interleukin-8, and interleukin-1 receptor antagonist in acute lung injury caused by local Shwartzman reaction, Pathol. Int. 47 (1997) 16-24.

[64] Johnston S.L., Natural and experimental rhinovirus infections of the lower respiratory tract, Am. J. Respir. Crit. Care Med. 152 (1995) 546552.

[65] Kamogawa O., Tomita Y., Kanebo M., Yamada S., Kubo M., Shimizu M., Isolation of porcine respiratory coronavirus from pigs affected with porcine reproductive and respiratory syndrome virus, J. Vet. Med. Sci. 58 (1996) 385-388.

[66] Kawashima K., Yamada S., Kobayashi H., Narita M., Detection of Porcine Reproductive and Respiratory Syndrome Virus and Mycoplasma hyorhinis Antigens in Pulmonary Lesions of Pigs Suffering from Respiratory Distress, J. Comp. Pathol. 114 (1996) 315-323.

[67] Kips J.C., Tavernier J., Pauwels R.A., Tumor necrosis factor causes bronchial hyperresponsiveness in rats, Am. Rev. Respir. Dis. 145 (1992) 332-336.

[68] Kozak W., Zheng H., Conn C.A., Soszynski D., Van der Ploeg L.H.T., Kluger M.J., Thermal and behavioral effects of lipopolysaccharide and influenza in interleukin-1 $\beta$-deficient mice, Am. J. Physiol. 269 (1995) R969-977.

[69] Kundin W.D., Hong Kong A-2 influenza virus infection among swine during a human epidemic in Taiwan, Nature 228 (1970) 857.

[70] Kunkel S.L., Standiford T., Kasahara K., Strieter R.M., Interleukin-8 (IL-8): the major neu- trophil chemotactic factor in the lung, Exp. Lung. Res. 17 (1991) 17-23.

[71] Kurokawa M., Imakita M., Kumeda C.A., Shiraki K., Cascade of fever production in mice infected with influenza virus, J. Med. Virol. 50 (1996) 152-158.

[72] Lanza I., Brown I.H., Paton D.J., Pathogenicity of concurrent infection of pigs with porcine respiratory coronavirus and swine influenza virus, Res. Vet. Sci. 53 (1992) 309-314.

[73] Larrick J.W., Wright S.C., Modulation of viral infections by cytokines, Mol. Biother. 4 (1992) 87-94.

[74] Laude H., Van Reeth K., Pensaert M., Porcine respiratory coronavirus: molecular features and virus-host interactions, Vet. Res. 24 (1993) 125150 .

[75] Laval A., Le Foll P., Gestin G., Reynaud G., Grippes et coronavirus respiratoire porcin: Études sérologiques dans dix élevages bretons, Recl. Méd. Vét. 167 (1991) 521-528.

[76] Le J., Vilcek J., Tumor necrosis factor and interleukin 1: cytokines with multiple overlapping biological activities, Lab. Invest. 56 (1987) 234248.

[77] Lee B.W., Bey R.F., Baarsch M.J., Larson M.E., Class specific antibody response to influenza A H1N1 infection in swine, Vet. Microbiol. 43 (1995) 241-250.

[78] Lefevre F., Mege D., L'Haridon R.L., Bernard S., de Vaureix C., La Bonnardière C., Contribution of molecular biology to the study of the porcine interferon system, Vet. Microbiol. 23 (1990) 245-257.

[79] Luheshi G., Rothwell N., Cytokines and fever, Int. Arch. Allergy Immunol. 109 (1996) 301307.

[80] Matsuda K., Tsutsumi H., Okamoto Y., Chiba C., Development of interleukin 6 and tumor necrosis factor- $\alpha$ activity in nasopharyngeal secretions of infants and children during infection with respiratory syncytial virus, Clin. Diagn. Lab. Immunol. 2 (1995) 322-324.

[81] Mengeling W.L., Lager K.M., Vorwald A.C., Diagnosis of porcine reproductive and respiratory syndrome, J. Vet. Diagn. Invest. 7 (1995) 3-16.

[82] Michel O., Nagy A.-M., Schroeven M., Duchateau J., Nève J., Fondu P., Sergysels R., Dose-response relationship to inhaled endotoxin in normal subjects, Am. J. Respir. Crit. Care Med. 156 (1997) 1157-1164.

[83] Midulla F., Villani A., Panuska J.R., Respiratory syncytial virus lung infection in infants: immunoregulatory role of infected alveolar macrophages, J. Infect. Dis. 168 (1993) 15151519.

[84] Moore B.K., Krakowka S., Cummins J.M., Robertson J.T., Changes in airway inflammatory cell populations in standardbred racehorses 
after interferon- $\alpha$ administration, Vet. Immunol. Immunopathol. 49 (1996) 347-358.

[85] Murtaugh M.P., Baarsch M.J., Zhou Y., Scamurra R., Lin G., Inflammatory cytokines in animal health and disease, Vet. Immunol. Immunopathol. 54 (1996) 45-55.

[86] Nayak D.P., Twiehous M.T., Kelley G.W., Underdahl N.R., Immunocytologic and histopathologic development of experimental swine influenza infection in pigs, Am. J. Vet. Res. 26 (1965) 1271-1282.

[87] Nelson S., Bagby G.J., Bainton B.G., Wilson L.A., Thompson J.J., Summer W.R., Compartmentalization of intraalveolar and systemic lipopolysaccharide-induced tumor necrosis factor and the pulmonary inflammatory response, $\mathrm{J}$. Infect. Dis. 159 (1989) 189-194.

[88] Nelson E.A., Christopher-Hennings J.C., Drew T., Wensvoort G., Collins J.E., Benfield D.A., Differentiation of US and European isolates of porcine reproductive and respiratory syndrome virus by monoclonal antibodies, J. Clin. Microbiol. 31 (1993) 3184-3189.

[89] Nielsen J., Botner A., Hematological and immunological parameters of 4 1/2-month old pigs infected with PRRS, Vet. Microbiol. 55 (1997) 289-294.

[90] Noah T.L., Becker S., Respiratory syncytial virus-induced cytokine production by a human bronchial epithelial cell line, Am. J. Physiol. 265 (1993) 472-478.

[91] Noah T.L., Henderson F.W., Wortman I.A., Devlin R.B., Handy J., Koren I.A., Becker S., Nasal cytokine production in viral acute upper respiratory infection of childhood, J. Infect. Dis. 171 (1995) 584-592.

[92] O’Toole D., Brown I., Bridges A., Cartwright S.F., Pathogenicity of experimental infection with "pneumotropic" porcine coronavirus, Res. Vet. Sci. 47 (1989) 23-29.

[93] Paton D.J., Brown I.H., Scott A.C., Done S.H., Edwards S., Isolation of a Lelystad virus-like agent from British pigs and scanning electron microscopy of infected macrophages, Vet. Microbiol. 33 (1992) 195-201.

[94] Patton L.M., Saggart B.S., Ahmed N.K., Leff J.A., Repine J.E., Interleukin- $1 \beta$-induced neutrophil recruitment and acute lung injury in hamsters, Inflammation 19 (1995) 23-29.

[95] Paul P.S., Vaughn E.M., Halbur P.G., Pathogenicity and sequence analysis studies suggest potential role of gene 3 in virulence of swine enteric and respiratory coronaviruses, Adv. Exp. Med. Biol. 412 (1997) 317-321.

[96] Pauli U., Porcine TNF: a review, Vet. Immunol. Immunopathol. 47 (1995) 187-201.

[97] Pensaert M., Ottis K., Vandeputte J., Kaplan M.M., Bachman P.A., Evidence for the natural transmission of influenza A virus from wild ducks to swine and its potential importance for man, Bull WHO 59 (1981) 75-78.

[98] Pensaert M., Callebaut P., Vergote J., Isolation of a porcine respiratory, non-enteric coronavirus related to transmissible gastroenteritis, Vet. Q. 8 (1986) 257-261.

[99] Peper R.L., Van Campen H., Tumor necrosis factor as a mediator of inflammation in influenza A viral pneumonia, Microb. Pathog. 19 (1995) 175-183.

[100] Plana J., Vayreda M., Vilarassa J., Bastons M., Rosell R., Martinez M., San Gabriel A., Pujols J., Badiola J.L., Ramos J.A., Domingo M., Porcine epidemic abortion and respiratory syndrome (mystery swine disease). Isolation in Spain of the causative agent and experimental reproduction of the disease, Vet. Microbiol. 33 (1992) 203-211.

[101] Pol J.M.A., van Dijk J.E., Wensvoort G., Terpstra C., Pathological, ultrastructural and immunohistochemical changes caused by Lelystad virus in experimentally induced infections of mystery swine disease (synonym: porcine epidemic abortion and respiratory syndrome (PEARS)), Vet. Q. 13 (1991) 137-143.

[102] Porteu F., Nathan C., Shedding of tumor necrosis factor receptors by activated human neutrophils, J. Exp. Med. 172 (1990) 599-607.

[103] Proud D., Gwaltney J.M., Hendley J.O., Dinarello C.A., Gillis S., Schleimer R.P., Increased levels of interleukin-1 are detected in nasal secretions of volunteers during experimental rhinovirus colds, J. Infect. Dis. 169 (1994) 1007-1013

[104] Riffault S., Eloranta M.L., Carrat C., Sandberg K., Charley B., Alm G., Herpes simplex virus induces appearance of interferon- $\alpha / \beta$-producing cells and partially interferon- $\alpha / \beta$-dependent accumulation of leukocytes in murine regional lymph nodes, J. Interferon Cytokine Res. 16 (1996) 1007-1014.

[105] Roberts N.J. Jr., Prill A.H., Mann T.N., Interleukin 1 and interleukin 1 inhibitor production by human macrophages exposed to influenza virus or respiratory syncytial virus, J. Exp. Med. 163 (1986) 511-519.

[106] Rossow K.D., Bautista E.M., Goyal S.M., Molitor T.W., Murtaugh M.P., Morrison R.B., Benfield D.A., Collins J.E., Experimental porcine reproductive and respiratory syndrome virus infection in one-, four- and 10-week-old pigs, J. Vet. Diagn. Invest. 6 (1994) 3-12.

[107] Rossow K.D., Collins J.E., Goyal S.M., Nelson E.A., Christopher-Hennings J., Benfield D.A., Pathogenesis of porcine reproductive and respiratory syndrome virus infection in gnotobiotic pigs, Vet. Pathol. 32 (1995) 361-373.

[108] Rylander R., Endotoxins, in: Boca Raton (Ed.), Organic Dusts: Exposure, Effects, and Prevention, Lewis Publishers, 1994, pp.7-10. 
[109] Sample A.K., Czuprynski C.J., Priming and stimulation of bovine neutrophils by recombinant human interleukin-1- $\alpha$ and tumor necrosis factor- $\alpha$, J. Leukoc. Biol. 49 (1991) 107-115

[110] Schindler R., Mancilla J., Endres S., Ghorbani R., Clark S.C., Dinarello C.A., Correlations and interactions in the production of interleukin- 6 (IL-6), IL-1, and tumor necrosis factor (TNF) in human blood mononuclear cells: IL-6 suppresses IL-1 and TNF, Blood 75 (1990) 40-47.

[111] Sharma S.A., Olchowy T.W.J., Yang Z., Breider M.A., Tumor necrosis factor- $\alpha$ and interleukin$1 \alpha$ enhance lipopolysaccharide-mediated bovine endothelial cell injury, J. Leukoc. Biol. 51 (1992) 579.

[112] Shi J., Goodband R.D., Chengappa M.M., Nelssen J.L., Tokach M.D., Mc Vey D.S., Blecha F., Influence of interleukin-1 on neutrophil function and resistance to Streptococcus suis in neonatal pigs, J. Leukoc. Biol. 56 (1994) 88-94.

[113] Smart S.J., Casale T.B., TNF- $\alpha$-induced transendothelial neutrophil migration is IL-8 dependent, Am. J. Physiol. 226 (1994) 238-245.

[114] Sirinarumitr T., Paul P.S., Kluge J.P., Halbur P.G., In situ hybridization technique for the detection of swine enteric and respiratory coronaviruses, transmissible gastroenteritis virus (TGEV) and porcine respiratory coronavirus (PRCV), in formalin-fixed paraffin-embedded tissues, J. Virol. Methods 56 (1996) 149-160.

[115] Skidmore S., Jarlow M.J., Interferon as a viral diagnostic test, J. Virol. Methods 16 (1987) 155158 .

[116] Solano G.I., Segalés J., Collins J.E., Molitor T.W., Pijoan C., Porcine reproductive and respiratory syndrome virus (PRRSV) interaction with Haemophilus parasuis, Vet. Microbiol. 55 (1997) 247-257.

[117] Standiford T.J., Kunkel S.L., Phan S.H., Rollins B.J., Strieter R.M., Alveolar macrophage-derived cytokines induce monocyte chemoattractant protein-1 expression from human pulmonary type II epithelial cells, J. Biol. Chem. 266 (1991) 99129918.

[118] Stevenson G.W., Van Alstine W.G., Kanitz C.L., Keffaber K.K., Endemic porcine reproductive and respiratory syndrome virus infection of nursery pigs in two swine herds without current reproductive failure, J. Vet. Diagn. Invest. 5 (1993) 432-434.

[119] Strieter R.M., Lukacs N.W., Standiford T.J., Kunkel S.L., Cytokines and lung inflammation: mechanisms of neutrophil recruitment to the lung, Thorax 48 (1993) 765-769.

[120] Subauste M.C., Jacoby D.B., Richards S.M., Proud D., Infection of a human respiratory epithelial cell line with rhinovirus. Induction of cytokine release and modulation of susceptibility to infection by cytokine exposure, J. Clin. Invest. 96 (1995) 549-557.
[121] Tamaru M., Tomura K., Sakamoto S., Tezuka K., Tamatani T., Narumi S., Interleukin-1 $\beta$ induces tissue- and cell type-specific expression of adhesion molecules in vivo, Arterioscler. Thromb. Vasc. Biol. 18 (1998) 1292-1303.

[122] Tanner W.G., Welborn M.B., Shepherd V.L., Tumor necrosis factor- $\alpha$ and interleukin- $1 \alpha$ synergistically enhance phorbolmyristate acetateinduced superoxide production by rat bone marrow-derived macrophages, Am. J. Resp. Cell Mol. Biol. 7 (1992) 379-384.

[123] Terajima M., Yamaya M., Sekizawa K., Okinaga S., Suzuki T., Yamada N., Nakayama K., Ohrui T., Oshima T., Numazaki Y., Sasaki H., Rhinovirus infection of primary cultures of human tracheal epithelium: role of ICAM-1 and IL-1ß, Am. J. Physiol. 273 (1997) L749-L759.

[124] Terpstra C., Wensvoort G., Pol J.M.A., Experimental reproduction of porcine epidemic abortion and respiratory syndrome (mystery swine disease) by infection with Lelystad virus: Koch's postulates fulfilled, Vet. Q. 13 (1991) 131-136.

[125] Tizard I.R., Interferons, in: Myers M.J., Murtaugh M.P. (Ed.), Cytokines in Animal Health and Disease, Marcel Dekker Inc, New York, 1995, pp. 1-59.

[126] Tosi M.F., Stark, J.M., Smith C.W., Hamedani A., Gruenert D.C., Infeld M.D., Induction of ICAM-1 expression on human airway epithelial cells by inflammatory cytokines: effects on neutrophil-epithelial cell adhesion, Am. J. Respir. Cell Mol. Biol. 7 (1992) 214.

[127] Tsutsumi H., Matsuda K., Sone S., Takeuchi R., Chiba S., Respiratory syncytial virus-induced cytokine production by neonatal macrophages, Clin. Exp. Immunol. 106 (1996) 442-446.

[128] Turner R.B., Weingand K.W., Yeh C.H., Leedy D.W., Association between interleukin- 8 concentration in nasal secretions and severity of symptoms of experimental rhinovirus colds, Clin. Infect. Dis. 26 (1998) 840-846.

[129] Ulich T.R., Watson L.R., Yin S., Guo K., Wang P., Thang H., del Castillo J., The intratracheal administration of endotoxin and cytokines, Am. J. Pathol. 138 (1991) 1485-1496.

[130] Urbain B., Prouvost J.-F., Beerens D., Ansay M., Gustin P., Acute effects of endotoxin inhalation on the respiratory tract in pigs: interaction with ammonia, Inhalation Toxicology 8 (1996) 947-968.

[131] Vacheron F., Rudent A., Perin S., Labarre C., Quero A.M., Guenounou M., Production of interleukin 1 and tumour necrosis factor activities in bronchoalveolar washings following infection of mice by influenza virus, J. Gen. Virol. 71 (1990) 477-479.

[132] Van Alstine W.G., Stevenson G.W., Kanitz C.L., Porcine reproductive and respiratory syndrome virus does not exacerbate Mycoplasma hyop- 
neumoniae infection in young pigs, Vet. Microbiol. 49 (1996) 297-303.

[133] Vandenbroeck K., Billiau A., Recent progress in the molecular characterization of porcine lymphokines, monokines and chemokines, in: Horzinek, M.C., Schijns, V. (Ed.), Cytokines in Veterinary Medicine, CAB International, UK, 1997, pp. 139-164.

[134] Vandenbroeck K., Fiten P., Opdenakker G., Billiau A., Two distinct interleukin-1- $\beta$ genes in the pig genome, Immunogenetics 40 (1994) 82.

[135] Vannier P., Disorders induced by the experimental infection of pigs with the porcine respiratory coronavirus, J. Vet. Med. B 37 (1990) 177-180

[136] Van Kessel K.M., Van Strijp J.A.G., Verhoef J., Inactivation of recombinant human tumor necrosis factor- $\alpha$ by proteolytic enzymes released from stimulated human neutrophils, J. Immunol. 147 (1991) 3862-3868.

[137] van Miert A.S., Van Duin C.T., Wensing T., Fever and changes in plasma zinc and iron concentrations in the goat. The effects of interferon inducers and recombinant IFN- $\alpha$, J. Comp. Pathol. 103 (1990) 289-300.

[138] Van Reeth K., Pensaert M., Experimental infections with different porcine respiratory coronavirus field isolates: clinical and virological aspects, in: Proc. 12th Congress Int. Pig Vet. Soc., Den Haag, The Netherlands, 1992, p. 152.

[139] Van Reeth K., Pensaert M., Porcine respiratory coronavirus-mediated interference against influenza virus replication in the respiratory tract of feeder pigs, Am. J. Vet. Res. 55 (1994) 12751281.

[140] Van Reeth K., Pensaert M., Prevalence of infections with enzootic respiratory and enteric viruses in feeder pigs entering fattening herds, Vet Rec. 135 (1994) 594-597.

[141] Van Reeth K., Nauwynck H., Pensaert M., Dual infections of feeder pigs with porcine reproductive and respiratory syndrome virus followed by porcine respiratory coronavirus or swine influenza virus: a clinical and virological study, Vet. Microbiol. 48 (1996) 325-335.

[142] Van Reeth K., Nauwynck H., Pensaert M., Bronchoalveolar interferon- $\alpha$, tumor necrosis factor$\alpha$, interleukin-1, and inflammation during acute influenza in pigs: a possible model for humans? J. Infect. Dis. 177 (1998) 1076-1079.

[143] Van Reeth K., Labarque G., Nauwynck H., Pensaert M., Differential production of proinflammatory cytokines in the pig lung during different respiratory virus infections: correlations with pathogenicity, Res. Vet. Sci. 67 (1999) 47-52.

[144] Van Reeth K., Nauwynck H., Pensaert M., Porcine respiratory coronavirus synergizes with bacterial lipopolysaccharide in the induction of respiratory disease in pigs: a potential role for tumour necrosis factor- $\alpha$, J. Med. Microbiol. (in press).

[145] Vogelzang P.F.J., van der Gulden J.W.J., Folgering H., Kolk J.J., Heederik D., Preller L., Tielen M.J.M., van Schayk C.P., Endotoxin exposure as a major determinant of lung function decline in pig farmers, Am. J. Respir. Crit. Care Med. 157 (1998) 15-18.

[146] Wang Z., Larsson K., Palmberg L., Malmberg P., Larsson P., Larsson L., Inhalation of swine dust induces cytokine release in the upper and lower airways, Eur. Respir. J. 10 (1997) 381-387.

[147] Warren E.J., Finck B.N., Scamurra R.W., Murtaugh M.P., Johnson R.W., Behavioral and physiological responses induced by peripheral immune stimulation are mimicked in pigs by central injection of porcine tumor necrosis factor$\alpha$, J. Anim. Sci. (Suppl. 1) 73 (1995) 92.

[148] Wesley R.D., Woods R.D., Hill K.T., Biwer J.D., Evidence for a porcine respiratory coronavirus, antigenically similar to transmissible gastroenteritis virus in the United States, J. Vet. Diagn. Invest. 2 (1990) 312-317.

[149] Wesley R.D., Woods R.D., Mc Kean J.D., Senn M.K., Elazhary Y., Prevalence of coronavirus antibodies in Iowa swine, Can. J. Vet. Res. 61 (1997) 305-308.

[150] Wong G.H.W., Goedel D.V., Tumor necrosis factors- $\alpha$ and $\beta$ inhibit virus replication and synergize with interferons, Nature 323 (1986) 819822.

[151] Yoon I.J., Joo H.S., Christianson W.T., Morrison R.B., Dial G.D., Persistent and contact infection in nursery pigs experimentally infected with porcine reproductive and respiratory syndrome (PRRS) virus, Swine Health and Production 1 (1993) 5-8.

[152] Zeman D., Neiger K., Jaeger M., Nelson E., Benfield D., Leslie-Steen P., Thomson J., Miskimins P., Daly R., Minehart M., Laboratory investigation of PRRS virus infection in three swine herds, J. Vet. Diagn. Invest. 5 (1993) 522-528.

[153] Zoja C., Wang J. M., Bettoni S., Sironi M., Renzi D., Chiaffarino F., Abboud H.E., Van Damme J., Mantovani A., Remuzzi G., Interleukin- $1 \beta$ and tumor necrosis factor- $\alpha$ induce gene expression and production of leucocyte chemotactic factors, colony-stimulating factors, and interleukin6 in human mesangial cells, Am. J. Pathol. 138 (1991) 991-1003.

[154] Zhu Z., Tang W., Ray A., Wu Y., Einarsson O., Landry M.L., Gwaltney J., Elias J.A., Rhinovirus stimulation of interleukin-6 in vivo and in vitro. Evidence for nuclear factor $\kappa \mathrm{B}$-dependent transcriptional activation, J. Clin. Invest. 97 (1996) 421-430. 